\title{
The Nexus between Fire and Soil Bacterial Diversity in the African Miombo Woodlands of Niassa Special Reserve, Mozambique
}

\author{
Ivete Sandra Alberto Maquia 1,2,3, Paula Fareleira ${ }^{4}$, Isabel Videira e. Castro ${ }^{4} \mathbb{D}$, Ricardo Soares ${ }^{4} \mathbb{D}$,

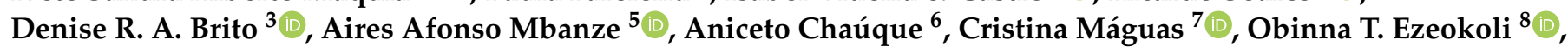 \\ Natasha Sofia Ribeiro ${ }^{6}\left(\mathbb{D}\right.$, Isabel Marques ${ }^{1, *(\mathbb{D})}$ and Ana I. Ribeiro-Barros ${ }^{1, *(\mathbb{D})}$
}

1 Forest Research Center, School of Agriculture, University of Lisbon, Tapada da Ajuda, 1349-017 Lisbon, Portugal; ivete.s.maquia@uem.ac.mz

2 TropiKMan Doctoral Program, NOVA SBE, 2775-405 Carcavelos, Portugal

3 Biotechnology Center, Eduardo Mondlane University, Maputo 3453, Mozambique; denise.brito@uem.mz

4 National Institute of Agricultural and Veterinary Research, I.P. (INIAV, I.P), 2780-157 Oeiras, Portugal; paula.fareleira@iniav.pt (P.F.); isabel.castro@iniav.pt (I.V.e.C.); ricardo.soares@iniav.pt (R.S.)

5 Faculty of Agrarian Science, Lúrio University, Niassa 3302, Mozambique; airesmbanze@unilurio.ac.mz

6 Faculty of Agronomy and Forest Engineering, Eduardo Mondlane University, Maputo 3453, Mozambique; achauque2012@gmail.com (A.C.); joluci2000@yahoo.com (N.S.R.)

7 Centre for Ecology, Evolution and Environmental Changes (cE3c), Faculty of Sciences, University of Lisbon, 1749-016 Lisbon, Portugal; cmhanson@fc.ul.pt

check for updates

Citation: Maquia, I.S.A.; Fareleira, P.; Videira e. Castro, I.; Soares, R.; Brito, D.R.A.; Mbanze, A.A.; Chaúque, A.; Máguas, C.; Ezeokoli, O.T.; Ribeiro, N.S.; et al. The Nexus between Fire and Soil Bacterial Diversity in the African Miombo Woodlands of Niassa Special Reserve, Mozambique. Microorganisms 2021, 9, 1562. https:// doi.org/10.3390/microorganisms 9081562

Academic Editor: Francisco Xavier Nascimento

Received: 23 June 2021

Accepted: 19 July 2021

Published: 22 July 2021

Publisher's Note: MDPI stays neutral with regard to jurisdictional claims in published maps and institutional affiliations.

Copyright: (c) 2021 by the authors. Licensee MDPI, Basel, Switzerland. This article is an open access article distributed under the terms and conditions of the Creative Commons Attribution (CC BY) license (https:/ / creativecommons.org/licenses/by/ $4.0 /)$.
8 Department of Microbiology and Biochemistry, University of the Free State, Bloemfontein 9300, South Africa; 2019875893@ufs4life.ac.za

* Correspondence: isabelmarques@isa.ulisboa.pt (I.M.); aribeiro@isa.ulisboa.pt (A.I.R.-B.)

Abstract: (1) Background: the Miombo woodlands comprise the most important vegetation from southern Africa and are dominated by tree legumes with an ecology highly driven by fires. Here, we report on the characterization of bacterial communities from the rhizosphere of Brachystegia boehmii in different soil types from areas subjected to different regimes. (2) Methods: bacterial communities were identified through Illumina MiSeq sequencing (16S rRNA). Vigna unguiculata was used as a trap to capture nitrogen-fixing bacteria and culture-dependent methods in selective media were used to isolate plant growth promoting bacteria (PGPB). PGP traits were analysed and molecular taxonomy of the purified isolates was performed. (3) Results: Bacterial communities in the Miombo rhizosphere are highly diverse and driven by soil type and fire regime. Independent of the soil or fire regime, the functional diversity was high, and the different consortia maintained the general functions. A diverse pool of diazotrophs was isolated, and included symbiotic (e.g., Mesorhizobium sp., Neorhizobium galegae, Rhizobium sp., and Ensifer adhaerens), and non-symbiotic (e.g., Agrobacterium sp., Burkholderia sp., Cohnella sp., Microvirga sp., Pseudomonas sp., and Stenotrophomonas sp.) bacteria. Several isolates presented cumulative PGP traits. (4) Conclusions: Although the dynamics of bacterial communities from the Miombo rhizosphere is driven by fire, the maintenance of high levels of diversity and functions remain unchanged, constituting a source of promising bacteria in terms of plant-beneficial activities such as mobilization and acquisition of nutrients, mitigation of abiotic stress, and modulation of plant hormone levels.

Keywords: Miombo; fire; 16SrRNA; rhizosphere; plant growth promoting bacteria; Brachystegia boehmii

\section{Introduction}

Soil microorganisms play crucial roles in ecosystem functioning, contributing significantly to soil structure and fertility as well as to plant responses to environmental drivers [1-3]. In association with climate and anthropogenic factors, the soil microbiome is a major ecological determinant of forest ecosystems [4]. One gram of forest soil harbors millions to billions of bacteria that mediate the overall soil dynamics, indicating ecosystem health and land use [5-8]. 
Tropical soil ecosystems are particularly diverse and complex, having a unique set of microbial functions with recognized potential for developing bio-based solutions, and yet remain largely understudied $[9,10]$. The most relevant tropical ecosystems (i.e., Amazonia, Congo, New Guinea forests, and Miombo-Mopane woodlands) are ranked among the top High Biodiversity Wilderness Areas (HBWA) [11,12]. Miombo is the most important and widespread type of vegetation from southern Africa, covering approximately 2 million $\mathrm{km}^{2}$, i.e., $70 \%$ of the Sudan-Zambezian phytoregion [13]. Together with the Mopane eco-region (ca. $0.5 \mathrm{~km}^{2}$ ), Miombo is among the five hotspots of unique species endemism [11]. Dominated by legume trees belonging to the genera Brachystegia, Julbernardia, and Isoberlinia [14], Miombo is a major provider of ecosystem goods and services through the provision of timber and nontimber products to more than 150 million rural and urban dwellers in the poorest countries of the world (revised by [15]). However, the increasingly growing human population, together with unsustainable management practices and climate pressure, impose major modifications in the ecoregion at the expense of biodiversity and ecosystem services [16-19].

Soil formation and conservation are among the major regulation and supporting services in the Miombo woodlands [15]. Miombo soils are mostly nutrient-poor and dry [14]; thus, the accumulation and decomposition of organic matter are of utmost importance for maintaining soil structure and fertility [20,21]. Ultimately, wildfires resulting from the combined action of climate, human, and animal pressures are the major woodland's drivers, undermining biodiversity composition, structure, and function [22,23], and may become major contributors to greenhouse gas (GHG) emissions [24]. At the same time, fires are important management tools [25] that are essential for the maintenance of the phytosociological structure of Miombo, as they contribute to regrowth and seed germination [15,26] as well as to soil mineralization and nutrient availability [27-29]. Thus, investigating fire and biodiversity dynamics in the Miombo woodlands is relevant to understand ecological processes. Considering that soil diversity is a key determinant of an ecosystem's stability [1-3], and that the Miombo woodlands are dominated by tree legumes with high resiliency to extreme environmental conditions $[14,15]$, the analysis of plant growth promoting bacteria (PGPB) is a crucial step to bridge the research gaps. PGPB comprise endosphere and rhizosphere bacteria that stimulate plant growth and development, and enhance plant performance [30]. These bacteria have been classified into four functional categories: (i) biofertilizers, which increase soil fertility and the accessibility of nutrients to plants; (ii) phytostimulators, which produce phytohormones that govern plant growth and development; (iii) bioremediators, which remove organic pollutants; and (iv) biocides, which mitigate the effect of pests and diseases [31].

Considering the global socio-ecological and economic importance of the Miombo woodlands and the inexistence of scientific studies addressing the complex nexus of factors driving the soil dynamics, in this paper we analyzed the effects of fire regime (high vs. low return intervals) and soil type (sandy, red, and oxic soils) in the diversity and functions of rhizosphere bacteria from the dominant Miombo legume tree, Brachystegia boehmii Taub. Three complementary approaches were used: (i) high throughput Illumina MiSeq sequencing of bacterial 16S rRNA gene; (ii) isolation of PGPB; and (iii) analysis of the effects of fire regime and soil type on PGP functions.

\section{Materials and Methods}

\subsection{Site Description}

The fieldwork was conducted in the Niassa Special Reserve (NSR; North Mozambique, Niassa Province) located between latitudes $12^{\circ} 38^{\prime} 048.67^{\prime \prime} \mathrm{S}$ and $11^{\circ} 27^{\prime} 05.83^{\prime \prime} \mathrm{S}$ and meridians $36^{\circ} 25^{\prime} 21.16^{\prime \prime} \mathrm{E}$ and $38^{\circ} 30^{\prime} 23.74^{\prime \prime} \mathrm{E}$. NSR is the largest (approx. $42.000 \mathrm{~km}^{2}$ ) and the most pristine area of Miombo (WWF, 2014; Figure 1). The climate is tropical sub-humid, with an average rainfall of $900 \mathrm{~mm}$ that increases from the east $(800 \mathrm{~mm})$ to the west (1200 $\mathrm{mm}$ ), and a mean annual temperature of $25^{\circ} \mathrm{C}$ during the dry season (May-October) and $30{ }^{\circ} \mathrm{C}$ during the wet season (November-April) [32]. Miombo woodlands cover more 
than $70 \%$ of the total area of the NSR and are composed of approximately 8500 plant species, half of which are endemic. Brachystegia spp., Julbernardia globiflora Benth. (Troupin), Dyplorhynchus condilocarpon (Müll.Arg.) Pichon, and Pseudolachnostylis maprouneifolia Pax, dominate the canopy cover [33,34], and a dense and continuous grass layer dominates the forest floor. NSR also has a high diversity of faunal species, including elephants, pala-pala, lions, wild dogs, leopards, buffalo, and more than 400 bird species [35].

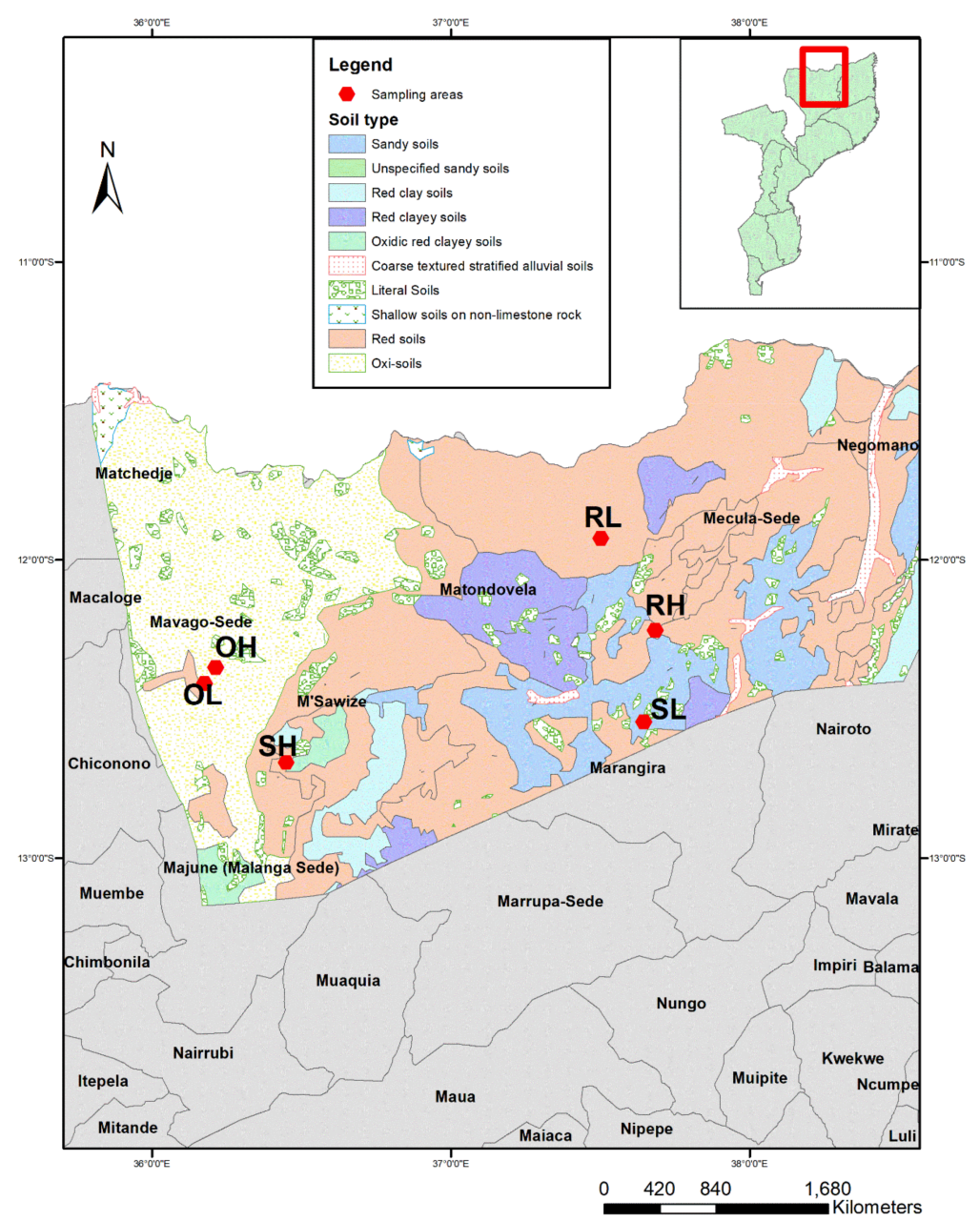

Figure 1. Geographic localization of the sampling sites (red dots) in the Niassa Special Reserve. Sampling points starting with S, R, and O indicate soil types of brownish-gray sandy soils, red soils of medium texture, and red oxi-soils of medium texture, respectively. Sampling points ending with $\mathrm{H}$ indicates high fire frequency (fire return interval $<1$ year) while $\mathrm{L}$ (fire return interval $>7$ years) indicates low fire frequency.

\subsection{Sampling}

The rhizosphere soil of Brachystegia boehmii was collected in three different soil types: brownish-gray sandy soils (sandy soils-S); red soils of medium texture (red soils-R); and red oxi-soils of medium texture (oxic soils-O) (Table 1). Considering each type of soils, samples were collected in sites with two different fire frequency regimes: low fire frequency ( $\mathrm{L}$, fire return interval $>7$ years) and high frequency $(\mathrm{H}$, fire return interval $<1$ year) (Figure 1). SH and SL depict samples from brownish-gray sandy soils for high and low fire frequency regime, respectively, RH and RL represent samples from red soils of medium texture for high and low frequency regimes, respectively, while $\mathrm{OH}$ and $\mathrm{OL}$ indicate samples from red oxi-soils of medium texture for high and low fire frequency regimes, respectively. Soil samples were collected at approximately $20 \mathrm{~cm}$ depth, in eight circular plots of $40 \mathrm{~m}$ diameter arranged in two contiguous parallel transects using the Riley 
and Barber's shake method [36]. A total of 24 rhizosphere soil samples were collected (4 replicates $\times 3$ soil types $\times 2$ fire frequencies) and preserved at $-80^{\circ} \mathrm{C}$ until DNA extraction.

Table 1. Description of soil types and sample codes (underlined Caps).

\begin{tabular}{ccc}
\hline Soil Type & Fire Frequency & Code \\
\hline Brownish-gray sandy soils & $\underline{\text { Low }}$ & SL \\
& $\underline{\text { High }}$ & SH \\
\hline \multirow{2}{*}{ Red soils of medium texture } & $\underline{\text { Low }}$ & $\mathrm{RL}$ \\
& $\underline{\text { High }}$ & $\mathrm{RH}$ \\
\hline \multirow{2}{*}{ Red oxic soils with medium texture } & Low & OL \\
& $\underline{\text { High }}$ & OH \\
\hline
\end{tabular}

\subsection{DNA Extraction, Amplification, and Sequencing of $16 S$ rRNA Genes}

DNA was extracted from $100 \mathrm{mg}$ soil samples using the DNeasy PowerSoil Kit (Qiagen, Germantown, MD, USA), following the manufacturer's instructions. Library preparation and Illumina MiSeq paired-end 300 bp sequencing run was performed by Macrogen, Seoul, South Korea. Briefly, DNA was first quantified by PicoGreen (Invitrogen, Waltham, MA, USA) using Victor 3 fluorometry, and the quality was determined on a 2100 Bioanalyzer (Agilent technologies, Santa Clara, CA, USA). To analyze the bacterial composition of the samples, the V3-V4 region of the 16S rRNA gene was amplified by polymerase chain reaction (PCR) under the following conditions: initial denaturation at $98{ }^{\circ} \mathrm{C}$ for $2 \mathrm{~min}$, followed by 35 cycles of denaturation at $95^{\circ} \mathrm{C}$ for $30 \mathrm{~s}$, primer annealing at $53{ }^{\circ} \mathrm{C}$ for $40 \mathrm{~s}$, extension at $72{ }^{\circ} \mathrm{C}$ for $1 \mathrm{~min}$, and a final extension phase at $72{ }^{\circ} \mathrm{C}$ for $5 \mathrm{~min}$. Specific primers 341F (5'-CCT ACG GGG NGG CWG CAG-3') and 805R (5'-GAC TAC HVG GGT ATC TAA TCC $\left.-3^{\prime}\right)$ and their adapters at the $5^{\prime}$ and $3^{\prime}$ ends of the DNA fragments were used [37]. The sizes and amounts of PCR-enriched fragments were verified on a 2100 Bioanalyzer (Agilent Technologies, Santa Clara, CA, USA). The libraries were normalized before sequencing with the Illumina MiSeq system (Illumina, San Diego, CA, USA).

\subsection{Assembly of Reads and Taxonomical Assignment}

Raw sequences were checked and trimmed using Quantitative Insight Into Microbial Ecology (QIIME) v.1.7.0 [38] to remove short and low-quality sequences that contained less than $200 \mathrm{bp}$, ambiguous bases, and had a minimum quality score of 20. Clean pairedend reads were merged using FLASH v. 1.2.11 [39]. Potential chimeric sequences were identified and removed by the UCHIME algorithm [40]. Unique sequences were grouped in operational taxonomic units (OTUs) with 97\% similarity using VSEARCH v.6.1.544 [37]. Pruning of OTUs with a low number of sequences $(<5)$ was conducted on a per-sample basis, as an OTU that is common in one sample may occur as a low-abundance contaminant in others due to cross-contamination. The most abundant sequence of each OTU was selected as representative. Taxonomy was assigned by searching for similar sequences, conducted with BLAST v2.2.29 using a similarity coefficient of $98 \%$, against the Greengenes 13_5 online database [41].

\subsection{Diversity Analysis}

QIIME v.1.9.1 platform was used to calculate the alpha diversity index of ShannonWiener $\left(\mathrm{H}^{\prime}\right)$ with the package alpha_diversity. The software was also used to produce rarefaction curves to compare the richness of different OTUs using the package alfa_rarefaction.py. Beta diversity was estimated by computing a phylogenetic tree based on unweighted UniFrac distances [42]. The UniFrac distance matrix was visualized using principal coordinates analysis (PCoA). A PERMANOVA test (999 permutations) based on a Bray-Curtis distance matrix calculated on normalized OTU counts was conducted to determine the effect of soil and fire frequency on bacterial community structure. A Kruskal-Wallis or a Mann-Whitney test was performed using Statistica v13.3 (StatSoft, Tulsa, OK, USA) [43] to 
determine the effects of soil type and fire frequency, respectively, on the OTU richness and diversity. Linear discriminant analysis (LDA) effect size (LEfSe) was performed to identify taxa with differential abundances (LDA score $>2.0$; Kruskal-Wallis $p<0.05$ ) between samples [44]. Thereafter, the top 200 differential features were summarized as a taxonomic cladogram using GraPhlAn v.1.1.3.1 [45].

\subsection{Functional Prediction}

Functional predictions of the bacterial community were conducted by AllGenetics \& Biology SL (www.allgenetics.eu) using the software PICRUSt2 [46]. We used the hidden state prediction tool, implemented in the castor R package [47] to normalize the data and predict gene families' profiles. To generate a finer resolution of the predicted changes within the metagenomes, we weighted the results of the prediction of gene families by the relative abundance of the OTUs to infer the metagenomes of the community, using the OTU abundances per sample. We mapped enzyme commission (EC) abundances onto gene pathways using MinPath [48] and the MetaCyc reactions database [49]. The resulting pathway abundance table represents how much each OTU contributed to the communitywide pathway abundance. We used the package STAMP [50] to perform statistical analysis of the functional profiles recovered using the two-sided Welch's $t$-test [51]. We compared multiple groups of samples (red vs. sandy vs. oxic soil) by computing an ANOVA/TukeyKramer test to determine significant differences between the metabolic pathways detected in each group. The Benjamini-Hochberg FDR [52] correction method was applied to the results and all features with an adjusted $p$-value $\geq 0.05$ were removed. To easily visualize the spread of the data in each group, we generated a principal component analysis (PCA) plot.

\subsection{Isolation and Characterization of Root Nodule Bacteria Using a Trap Host Legume}

The promiscuous tropical legume plant, Vigna unguiculata (cowpea), obtained from a local landrace from Manica, Mozambique (GUR; see [53,54]), was used as a trap host for rhizobia bacteria, following the protocol described by [9]. Briefly, seeds were surfacesterilized, soaked in sterilized water, and germinated in an agar and water solution of $0.8 \%$ (weight/volume). Seedlings were transferred to jars containing inert sand and $50 \mathrm{~mL}$ of N-free Jensen plant nutrient medium [55]. A diluted soil solution (1:10) from each sample was independently applied on the roots of individual seedlings ( $1 \mathrm{~mL} /$ seedling). A non-inoculated positive $\mathrm{N}$-control supplied with $1.75 \% \mathrm{KNO}_{3}(\mathrm{TN})$ and a non-inoculated $\mathrm{N}$-free negative control supplemented with $1 / 4$ liquid Jensen medium control (T0) were also prepared. Five replicates were performed for each soil type. Plants were grown in a growth chamber (photoperiod of $16 \mathrm{~h}$ day and $8 \mathrm{~h}$ night and temperature $23^{\circ} \mathrm{C}$ day and $18^{\circ} \mathrm{C}$ night) for 4 weeks and in a greenhouse for a further 7 weeks. Plants were watered with liquid Jensen medium once per week. The presence of nodules and the nodulation phenotype were examined after 11 weeks. The dry weights of shoots were calculated and used to determine the index of symbiotic effectiveness (Es), according to Ferreira and Marques [56]: $\mathrm{Es}=(\mathrm{Xs}-\mathrm{XT0} / \mathrm{XTN}-\mathrm{XT0}) \times 100$, where $\mathrm{Xs}$ represents the mean dry weight of inoculated plants $\pm \mathrm{SD} ; \mathrm{XTN}$ represents the mean dry weight of plants from nitrogen control and XT0 represents the mean dry weight of uninoculated plants. The data were analyzed by one-way analysis of variance (ANOVA) with the Statistica v. 13.0 software (StatSoft, Tulsa, OK, USA), using the Fisher's least significant difference (LSD) test at $p \leq 0.05$.

Root nodules were then surface-sterilized and crushed. A droplet of the nodule suspension was streaked on a yeast mannitol agar (YMA) plate containing Congo red [57]. Plates were incubated at $28^{\circ} \mathrm{C}$ in the dark and bacterial growth was followed for 10 days. Isolate purity was checked by examining the colony morphology and Congo red absorption. Subculturing was conducted when more than one type of colony was present. 


\subsection{Isolation of Rhizosphere Bacteria and Characterization of In Vitro Plant Growth Promoting Activities}

All rhizosphere samples (SH, SL, OH, OL, RH, and RL) were used for the isolation of soil bacteria according to [9]. Briefly, $2 \mathrm{~g}$ aliquots of the soil samples were suspended in $18 \mathrm{~mL}$ of $0.85 \% \mathrm{NaCl}$, serially diluted (ten-fold), and plated on Tryptone-Yeast Agar (TYA) [58] and Burk's agar [59]. Plates were incubated at $30^{\circ} \mathrm{C}$ and single colonies were selected based on their morphology and repeatedly transferred to fresh agar plates until purified. Isolated bacteria were routinely grown in Tryptone-Yeast (TY) broth and TYA.

Soil bacterial isolates were evaluated for in vitro activities related to the promotion of plant growth using the same procedures as described previously [60]. For evaluation of aerobic growth in the absence of nitrogen, the isolates were plated on Burk's N-free agar and growth was evaluated after incubation for $5-7$ days at $30^{\circ} \mathrm{C}$. The production of auxins was evaluated according to [61], as described in [60]. Siderophore production was determined by the chrome-azurol (CAS) assay [62], modified by [63]. The formation of orange haloes around colonies was considered indicative of siderophore production [62]. The ability to solubilize mineral phosphate was evaluated in yeast-extract-dextrose (YED) agar plates supplemented with $5 \mathrm{~g} \mathrm{~L}^{-1} \mathrm{Ca}_{3}\left(\mathrm{PO}_{4}\right)_{2}$ [64]. Cellulase activity was assayed on agar plates as described by [63], according to the methods of [65-67]. Briefly, bacteria were inoculated on plates containing N-Fixing bacteria $(\mathrm{NFb})$ agar medium supplemented with $0.5 \%$ tryptone and $0.2 \%$ carboxymethylcellulose. After incubation at $30^{\circ} \mathrm{C}$ for three days, the plates were covered with Congo red solution $\left(1 \mathrm{mg} \mathrm{mL}^{-1}\right)$ for $30 \mathrm{~min}$ to facilitate the distinction of orange halos around the bacterial growth.

\section{Results and Discussion}

\subsection{Sequencing and Distribution of OTUs}

A total of 5,429,179 raw 16S rRNA gene sequence reads were obtained from all 24 samples. After removal of low-quality sequences and chimeras, 629,400 sequence reads were obtained with an average of 26,225 sequences per sample and $57.83 \%$ GC content (average of four replicates; Table S1). Rarefaction curves for each of the samples reached a plateau, indicating sufficient depth to capture 16S rRNA gene diversity (Figure S1).

Red soils from high fire frequency sites $(\mathrm{RH})$ presented the highest number of OTUs (1391) and oxi-soils from low fire frequency sites (OL) presented the lowest number (977: Figure 2A). Nevertheless, independent of the soil type and fire regime, the observed changes were not statistically significant $(\mathrm{H}=3.04, p=0.22)$. However, the influence of fire on soil bacterial diversity was reflected by an increase in the Shannon index in all high-frequency fire sites (Figure $2 ; \mathrm{H}=1.81, p=0.41$ ). The PCA analysis showed some spatial separation of oxi-soils from the other samples (Figure 2B).

Altogether, these results have shown that the bacterial diversity in the Miombo rhizosphere is highly diverse, and apparently more conserved within oxi-soils $(\mathrm{O})$. These contrast with a similar study performed in another important savanna ecosystem, the Mopane woodlands [9], where the rhizobacteria were found to be less abundant (700-800 OTUs vs ca. 1000-1200) and less diverse (Shannon H index ca. 4 vs ca. 7-8) than the results found here [9]. The results also contrasted with those observed in the subtropical Laurisilva forest, where fire drastically reduced bacterial abundance (from ca. 700-800 to ca. 300 OTUs) [68]. Thus, soil dynamics depend on a complex nexus of several factors, including anthropogenic and environmental parameters $[27,69,70]$ that are probably site-specific. In the cases of the savanna ecosystems (including Miombo and Mopane), wildfires are among the major evolutionary drivers undermining the development of fire tolerance and recovery strategies in the endemic vegetation [71]. Our focal species, Brachystegia boehmii, is adapted to high fire frequencies, and there seems to be a pyrodiversity effect, i.e., an increase in genetic diversity driven by fire [72,73], which, according to our Shannon diversity results, is also associated with the rhizobacteria community $[74,75]$, likely with a positive impact in fire tolerance. 


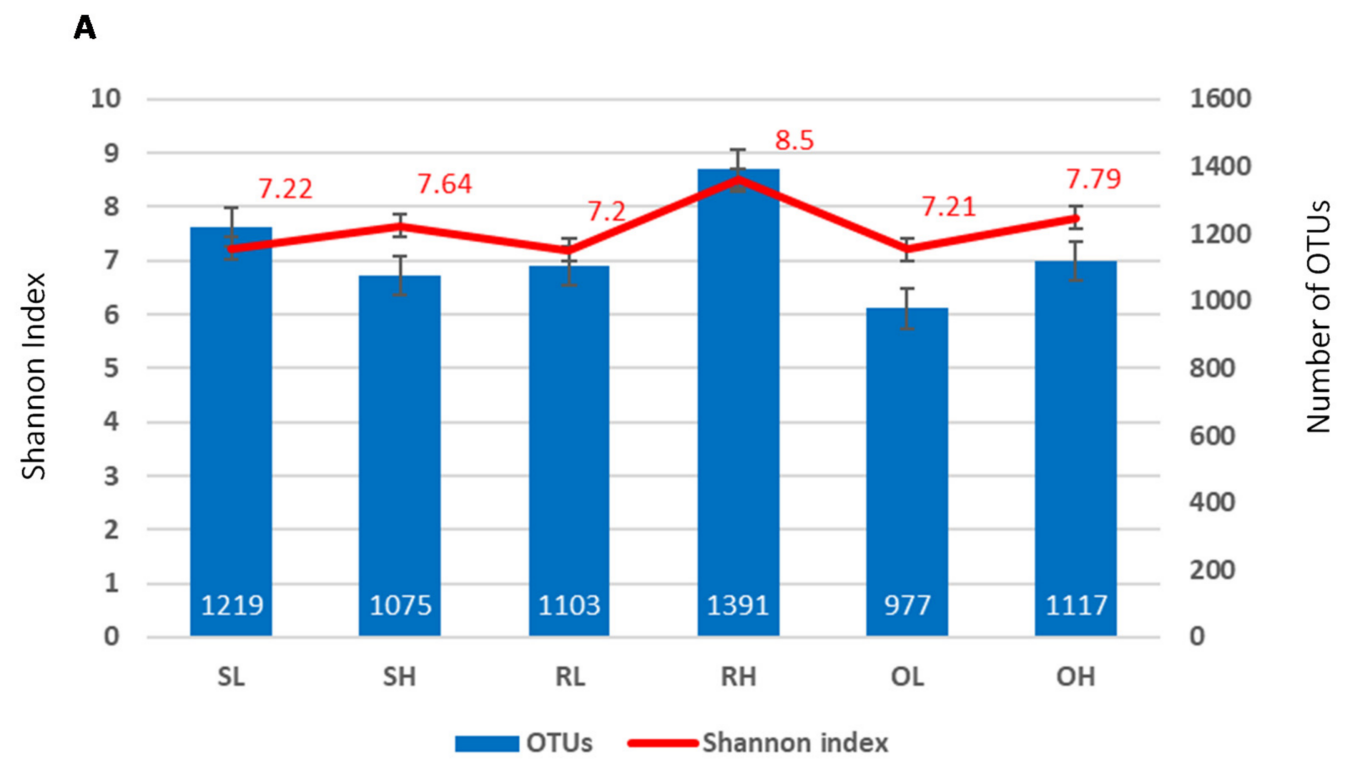

B

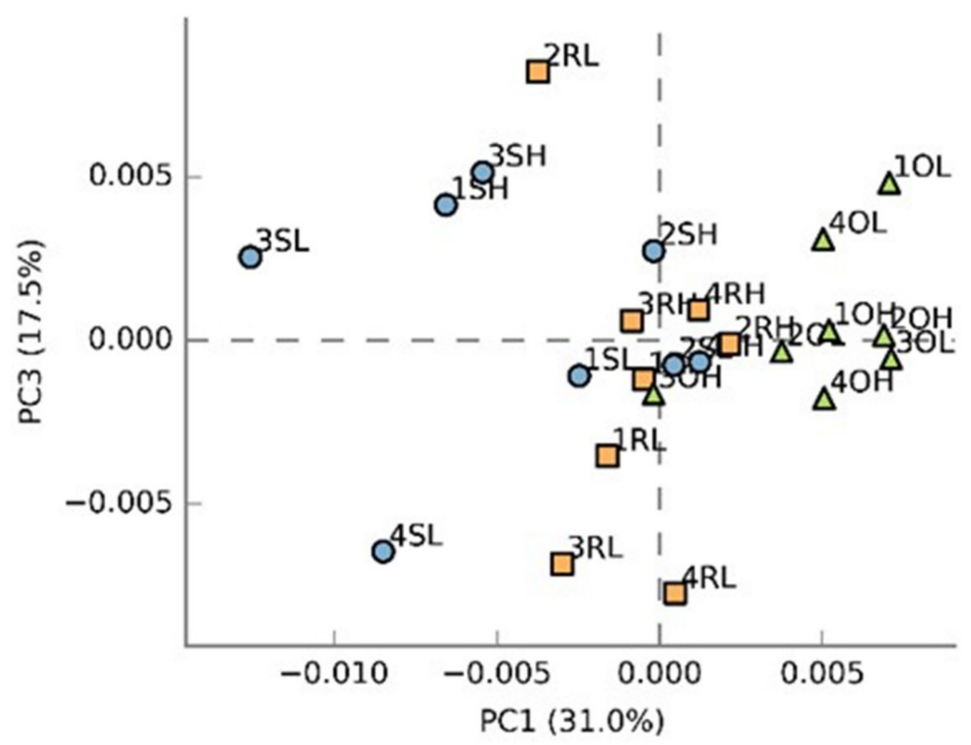

Figure 2. (A) Bacterial diversity in soils considering different rhizosphere samples (x-axis). (B) Principal component analysis (PCA) of bacterial communities in the different soil samples. S: sandy soils; R: red soils; O: red oxi-soils. H: high fire frequency; L: low fire frequency. Colors preceding the sample codes indicate one type of sample.

\subsection{Taxonomic Composition of the Microbial Communities}

In total, OTUs represented 17 phyla, 50 classes, 104 orders, 212 families, 565 genera, and 1057 species. The most abundant phylum was Actinobacteria $(39.49 \pm 12.89 \%)$, followed by Proteobacteria $(19.54 \pm 7.25 \%)$ and Acidobacteria (12.75 $\pm 4.79 \%)$ that, together, accounted for more than $72.43 \pm 5.05 \%$ of the relative abundance of sequence reads from all samples (Figure 2). An average of 7.31\% OTUs could not be identified (S: 5.99\%; R: 5.73\%; O: $10.21 \%$; Figure 2).

The abundance of Actinobacteria showed significant differences between soils, fire, and the interaction of both factors (Table S2). Actinobacteria was negatively affected by fire in sandy (S) and red (R) soils, which was significantly more abundant under regimes of low fire frequency (LFF) than under high fire frequency (HFF) (Figure 3). In the case of oxi-soils (O), HFF promoted a higher abundance of Actinobacteria. The abundance of Proteobacteria was significantly affected by fire (Table S2), which was more frequent under HFFs. The 
abundance of Acidobacteria showed no significant differences between fire frequencies, soils, and their interaction (Table S2).

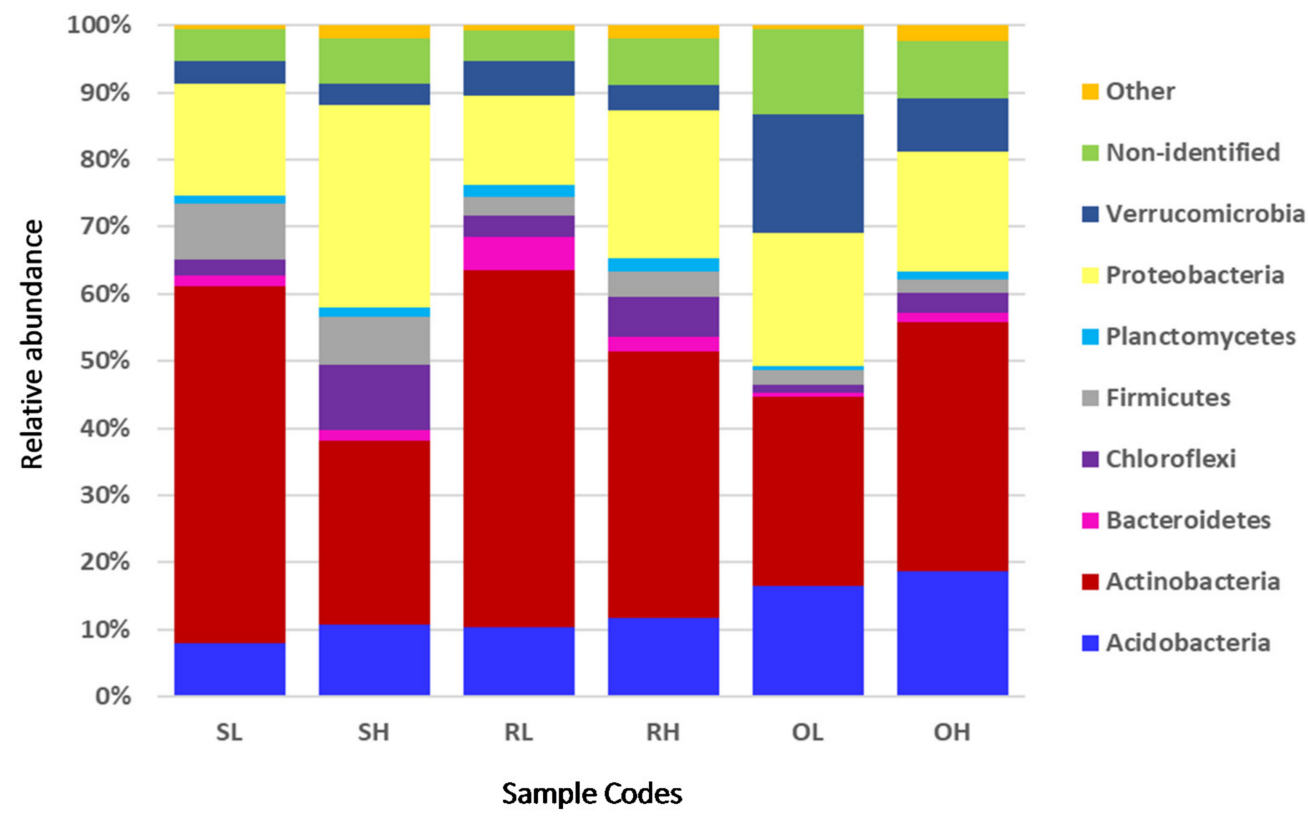

Figure 3. Relative abundance of bacterial phyla in the rhizosphere of Brachystegia boehmii sampled in three different soils under low and high fire frequencies. Sample codes follow Figure 1. Rare phyla $(<1 \%)$ were grouped as Other.

These phyla are frequently reported in the soils of other forest ecosystems $[9,68,76,77]$ comprising ubiquitous bacteria with a multiplicity of ecological functions such as soil fertilization, bioremediation and plant nutrition, growth, and protection $[1,78,79]$. In general, the bacterial variation patterns imposed by HFF followed the same trend in $S$ and $\mathrm{R}$ soils, contrasting with $\mathrm{O}$ soils. This was unexpected, as from a physical and chemical point of view, $\mathrm{R}$ and $\mathrm{O}$ soils are more similar, although all Miombo soils are generally nutrient-poor, acidic, and have a low cation exchange capacity [14]. Plausible explanations for this discrepancy may be the severity of the burnings as well as the phytosociological status at the sampling sites $[15,68]$.

Among the classifiable phylotypes, three dominant bacterial genera were found across all soil samples, including Gaiella $(8.82 \pm 3.81 \%)$, Chthoniobacter $(5.75 \pm 5.29 \%)$, and Solirubrobacter ( $5.53 \pm 2.98 \%)$, all which were significantly affected by fire, type of soil, and their interaction (Table S3). HFF significantly decreased the abundance of Gaiella, except in $\mathrm{O}$ soils (Figure 4). Fire had no impact on the abundance of Chthoniobacter in $\mathrm{S}$ and R soils, but in O soils the abundance of this genus decreased significantly under HFF (Figure 4). Solirubrobacter was negatively affected by HFF in S and R soils but positively affected in O soils. The common major genus Saccharopolyspora was significantly affected by soil type (Table S3) and was more abundant in S and R soils under LFF but negligible under HFF (Figure 4). The presence of this genus in O soils was minimal, with a slightly higher abundance under HFF compared to LFF regime. The abundance of the genus Bacillus was also affected by the type of soil (Table S3) and was more abundant in $\mathrm{S}$ soils but significantly lower in R soils and negligible in O soils (Figure 4; Table S3). 


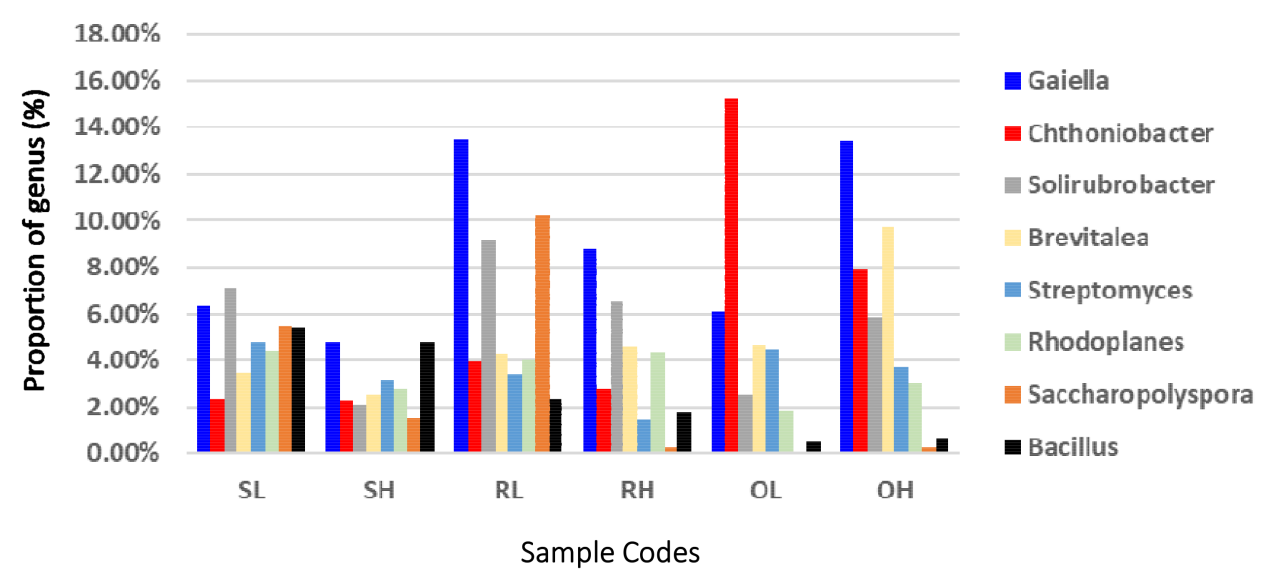

Figure 4. Relative abundance of the most frequent bacterial genera ( $>2 \%$ across all samples) in the rhizosphere of Brachystegia boehmii. Sample codes follow Figure 1.

The ecological role of Gaiella is largely unknown, but studies suggest a close phylogenetic relationship with thermophilic, halotolerant, and radiotolerants bacteria [80,81]. Thus, its presence upon fire may be related to thermotolerance [82]. Additionally, the presence of this genus is widely reported and related to: (i) antibiotic resistance and denitrification, thus being a potential source of nitrous oxide, a major greenhouse gas [83]; (ii) production of phtalides, organic compounds with antimicrobial, insecticidal, cytotoxic, and anti-inflammatory properties, among others [84]; and (iii) metabolization of organic compounds and nutrient cycling $[85,86]$. Similarly, the few studies available regarding the environmental role of Chthoniobacter suggest its involvement in the transformation of organic compounds $[87,88]$, possibly contributing to the cycling of carbon by the degradation of various complex carbohydrates, such as cellulose [89]. The same suggestion applies to the genus Solirubrobacter which has been described as the most dominant in different soil ecosystems, with functional analyses supporting a role in the nitrogen cycle and as a source of bioactive compounds [84]. The environmental role of Brevitalea is not yet described, but its occurrence was reported in savanna soils [90]. Recent studies suggest that the presence of Rhodoplanes in a consortia of rhizosphere bacteria is related to soil restauration [91-94] and nitrogen cycling $[95,96]$, while the halophytic Saccharopolyspora that has been reported in several saline environments (salt pans, mountains, lakes, salterns, and in the date palm rhizosphere) is related to the production of biocompounds [97,98].

A total of 27 discriminative features (linear discriminant analysis (LDA) score $>2$ and Kruskal-Wallis $p<0.05$ ) were identified between soil samples following a sample-wide LDA effect size (LEfSe) analysis (data not shown). The top discriminative features are shown in Figure 5. Of these, the classifiable genus-level features differentially more abundant in OL were: Acidibacter, highly tolerant to transition metals, as well as to arsenic [99]; Acidobacterium, related to organic matter transformation in forest soils [100], which is considered an indicator for soil fertility and plant health [101]; Desulfohalophilus, described as extreme halophilic sulfate- and arsenate-respiring bacteria [102]; Edaphobacter, whose presence has been reported in heavy metal contaminated soils [103] and more recently indicated as a potential source for bioelectricity production from sludge matrices [104]; and Paraburkholderia, identified as the main nitrogen-fixing microsymbionts of Mimosa tenuiflora from Caatinga (tropical dry forests) [105]. Actinokineospora was differentially more abundant in $\mathrm{OH}$. This genus constitutes a promising source of a wide range of bioactive compounds of pharmaceutical interest [106-109]. Zavarzinella is likely involved in the degradation of organic matter [110] and Microlunatus, a strong candidate to manage environmental pollution [111], was differentially abundant in RL, while Pirellula, a potential indicator of desertification [112], and Virgisporangium, of yet unknown function, were more abundant in RH. Finally, Xylanimicrobium, a novel petroleum hydrocarbon degrading bacterium [113], was differentially more abundant in SL, while there was no genus-level phylotype differentially abundant in SH compared with the other sites (Figure 5). These 
results reveal a clear impact of soil and fire on the plant's rhizosphere, reinforcing the importance of the microbial flora of Miombo for new bio-based solutions.

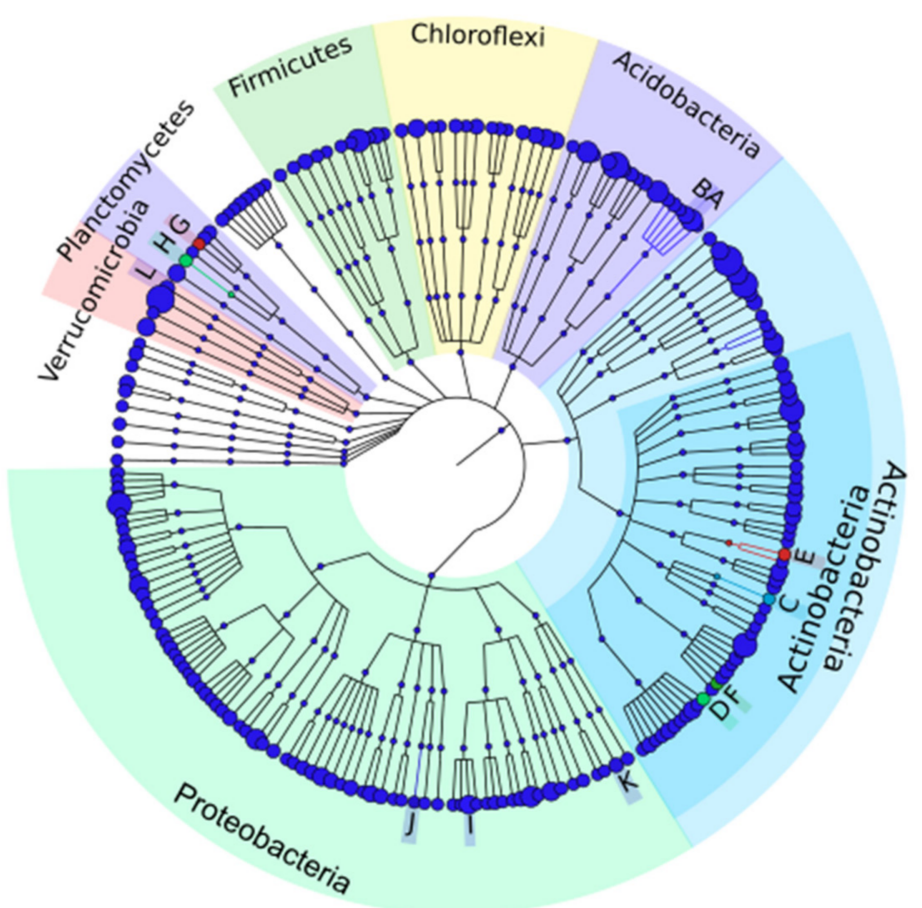

\begin{tabular}{|c|}
\hline Sampling site \\
OH \\
$\mathrm{OL}$ \\
$\mathrm{RH}$ \\
$\mathrm{RL}$ \\
$\mathrm{SL}$ \\
$\mathrm{SH}$ \\
External annotation \\
(Genus taxonomic rank) \\
A: Acidobacterium \\
B: Edaphobacter \\
C: Xylanimicrobium \\
D: Virgisporangium \\
E: Microlunatus \\
F: Actinokineospora \\
G: Zavarzinella \\
H: Pirellula \\
I: Paraburkholderia \\
J: Desulfohalophilus \\
K: Acidibacter \\
L: Temimicrobium \\
\hline
\end{tabular}

Figure 5. Differentially abundant genera assessed using LEfSE. Only genera with a LDA score $>2.0$ and Kruskal-Wallis $p<0.05$ are displayed.

PICRUSt2 identified 413 functional categories with a high degree of homology between samples (Figure S2). A top pathway (PWY-3781), which is involved in aerobic respiration I (cytochrome c), was found in all samples (Table S4; Figure S2). However, this pathway was more abundant in soils from LFF sites than from HFF $(\mathrm{F}=1.25 ; p=0.027)$. The type of soil also influenced the abundance of this pathway $(\mathrm{F}=1.33 ; p=0.022)$, which was more often under $\mathrm{O}$, then followed by $\mathrm{R}$, and to a lower extent, $\mathrm{S}$ soils (Table S5). Soil respiration plays an important role in nutrient cycles, such as carbon and nitrogen, and is therefore an important indicator of environmental changes [114]. The results suggest an elevated rate of bacterial activity in the soils [115], reflecting the resilience of bacteria to poor soils and high temperatures [9]. Nevertheless, their contribution to GHG emissions should also be addressed with caution, as this is a major issue in the Miombo woodlands [24].

\subsection{Vigna unguiculata as a Trap for Rhizobia Bacteria}

Considering the limitations of NGS on species identification, we further used Vigna unguiculata (cowpea) as a trap host to identify PGP bacteria present in the soil. Inoculation of cowpea plants with soil samples increased shoot dry weight to levels comparable and even higher than those of control plants supplied with nitrogen (Figure 6; Table S5), suggesting that the symbiosis with rhizobia bacteria was active.

Most Es values were higher than $75 \%$, indicating the presence of rhizobia strains highly effective in nitrogen fixation in almost all cases, except for the rhizobial population of $\mathrm{SH}$, which showed the lowest value $(\mathrm{Es}=42.18 \%)$. 


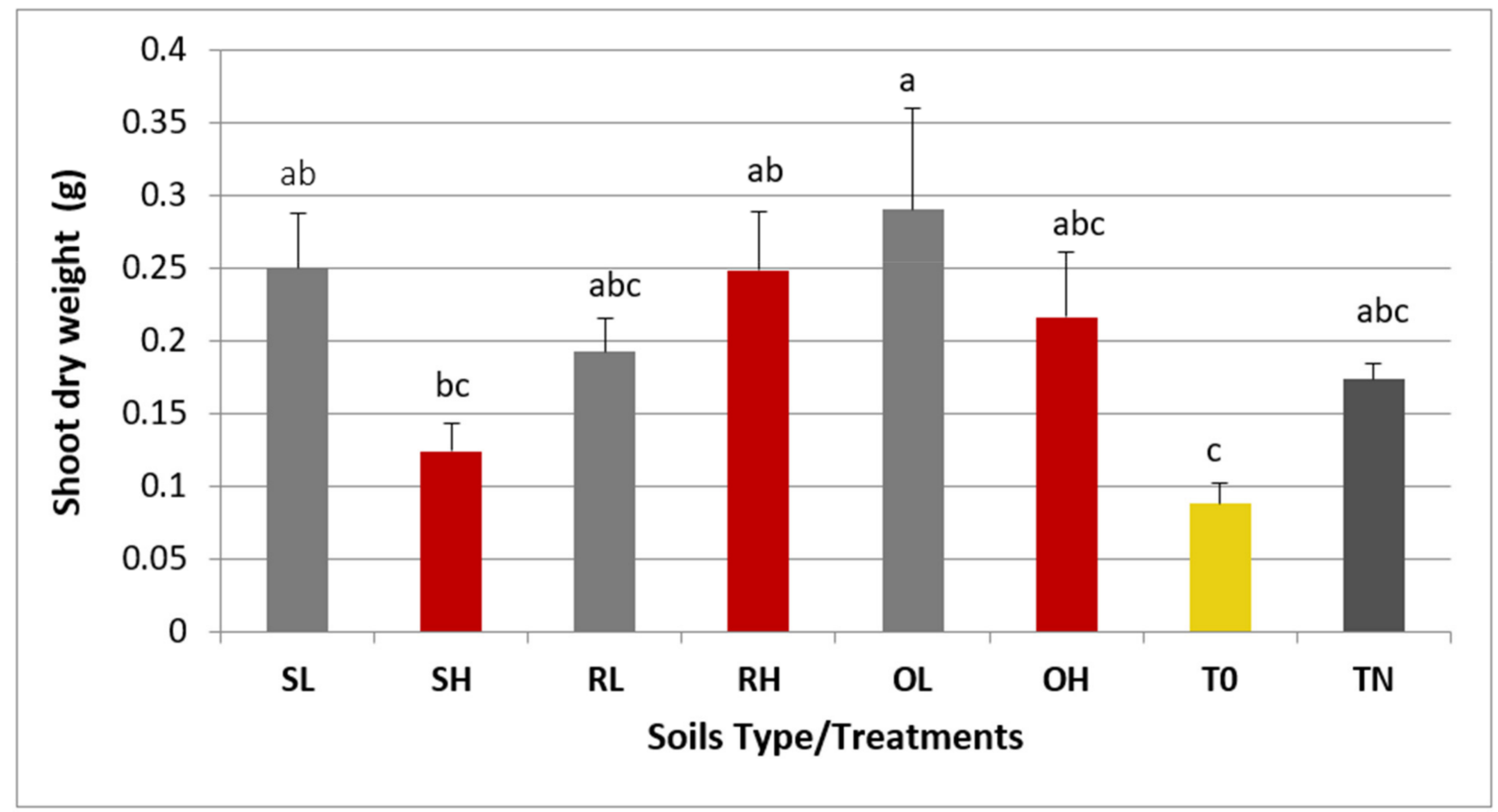

Figure 6. Dry weight of Vigna unguiculata plants inoculated with different soil samples. Population codes follow Figure 1. Uninoculated plants supplied either with nitrogen (TN) or without mineral N (T0) were also included. Values of shoot dry weight are the average \pm SE of five replicates/soil type. Different letters ( $a, b$, and $c)$ above the columns express significant differences between treatments (including plants inoculated with the soil samples, TN, and T0) according to the Fisher's LSD test at $p \leq 0.05$.

A total of 64 isolates were purified from $V$. unguiculata nodules, $82.8 \%$ of which belonged to the phylum Proteobacteria (53 isolates) and only $4.7 \%$ belonging to phylum Firmicutes (three isolates). The remaining $12.5 \%$ belonged to unidentified bacteria (eight unknown) (Table S6). Fourteen genera were successfully identified, nine of which were nitrogen-fixers (diazotrophs), namely, the symbiotic Mesorhizobium sp. (six isolated: SL9B, RH5A, RH9A, RH13A, RH11A, and OH11A), Neorhizobium galegae (RL16A), Rhizobium sp. (seven isolates: SL3, RL10B, RL10C, RL11A, OL2A, OL6A, and OH3BC), Ensifer adhaerens (three isolates: RL17, RH14A, and RH18A); and the nonsymbiotic Agrobacterium sp. (10 isolates: SL9C, RL4C, RL5B, RL14B, RL20, RH6A, RH12A, OL5A, OH10A, and OH12A), Cohnella sp. (SL4), Herbaspirillum huttiense (SH3A), Pseudomonas sp. (four isolates: SH5A, RL11B, OL1A, and OL4), and Stenotrophomonas sp. (13 isolates: SL10AB, SL10AC, RL6A, OL2B, OL2C, OL7A, OL10A, OL12A, OL13A, OL14A, OL15A, OL16A, and OH7A). Most of these bacteria have important applications as PGP. These results confirm those obtained by other authors [116-119], who showed that in addition to rhizobia, other bacteria can frequently inhabit the interior of nodules without causing damage or disease and are thus considered nodule endophytic bacteria. In general, fire had a negative effect on the diversity of the trapped bacteria and bacterial richness was dependent on the soil type, with higher levels in $\mathrm{R}$, intermediate levels in $\mathrm{O}$, and lower levels in $\mathrm{S}$.

The Stenotrophomonas sp., particularly S. maltophilia was the predominant bacteria in the isolates in all soil types (SL10AC, RL6A, OL2B, OL2C, OL10A, OL12A, OL14A, OL15A, and OH7A), which was more prevalent in low frequency fire of oxic soil types and absent in sandy and red soils. Studies have demonstrated the potential of these bacteria in biological control against Ralstonia solanacearum, a bacterium that causes potato brown rot [120]. This ability as a biocontrol agent is related to antimicrobial and insecticidal properties due to the production of several bioactive compounds [121,122]. These bacteria secrete siderophores, improving iron availability [122], and are also important for bioremediation [122,123]. Additionally, they produce phytohormones that promote root and seedling growth $[124,125]$. 
The second most predominant bacteria were Agrobacterium sp. In addition to fixing nitrogen, this genus is also involved in the production of phytohormones [126] and species such as $A$. tumefaciens (OL5A) and $A$. rhizogenes (RL20) may be pathogenic, constituting important plant transformation tools [127-129].

Rhizobium sp. was the third most predominant genus found. Together with Allorhizobium, Azorhizobium, Bradyrhizobium, Mesorhizobium, and Sinorhizobium rhizobia, these bacteria form nitrogen-fixing root nodules on leguminous species, although in species belonging to Caesalpinioideae, as B. boehmii, this association seems to be rare $[130,131]$ though it is poorly studied. Our results showed that the rhizosphere of $B$. boehmii has a high diversity regarding the rhizobia genera, which contrasts with other tree legumes, such as Faidherbia albida, Albizia versicolor [132] and Colophospermum mopane [9], where only Bradyrhyzobium has been identified.

Although less represented, Pseudomonas has also been isolated from trapping cowpea nodules and is indicated as a key PGPB [60]. Studies conducted on Pelargonium graveolens demonstrated the production of siderophore, phytohormones, and inorganic phosphate solubilization by P. monteilii (RL11B) [133] and growth promotion in Arabidopsis thaliana and Lactuca sativa by P. nitritireducens (OL4) [134].

Variovorax (RL5A, RL13A, RL14A, and RL19B) has been identified as PGPB in Chinese cabbage and green pepper through siderophores and 1-aminocyclopropane-1-carboxylic acid (ACC) deaminase production [135]. ACC deaminase additionally helps plant development under adverse environmental conditions [136].

Other species isolated were Lactobacillus reuteri (RH5B and RH8A), Lysobacter soli (RL8DB), Rubrimonas shengliensis (RL7A), and Xanthomonas oryzae pv. oryzae (SH1 and SH8). There are no studies describing the role of L. reuteri, L. soli, or R. shengliensis in soils; however, X. oryzae pv. oryzae is described as the most important rice pathogen [137]. This opens the door to new areas of research to understand the role of these bacteria in Miombo soils.

\subsection{Characterization of In Vitro Plant Growth Promoting Activities and Taxonomic Analysis of Bacteria Isolated from Soils}

Eight bacterial isolates with plant growth promoting activities were recovered from soils, including one isolate from sandy soil, three from red soils, and four from oxic soils (Table 2). Isolates from sandy and oxic soils were obtained with TYA as an isolation medium, whereas isolates from red soil were obtained using Burk's N-free medium. Based on the sequence analysis of the $16 \mathrm{~S}$ rRNA gene, all isolates were assigned to the phylum Proteobacteria, namely Burkholderia sp. (5RHB and 6RHB), Caballeronia zhejiangensis (4RHB), and Variovorax defluvii (10OHA), which belong to Burkhoderiales; and Microvirga sp. (10SLA) and Rhizobium sp. (4OLA, 5OLA, and 5OHA), which belongs to Rhizobiales.

All isolates were able to grow aerobically in a nitrogen-free medium (Table 2) and are therefore likely to be nitrogen fixers potentially contributing to the nitrogen uptake of B. boehmii. Although there are no studies that confirm nitrogen fixation by C. zhejiangensis, all other bacteria were previously described as nitrogen fixers [138-143]. The ability to solubilize phosphate was not detected in any of the isolates. Isolates from all soil types were able to produce the plant hormone indole-3-acetic acid (IAA) (Table 2), namely Microvirga sp. (10SLA) in sandy soils, Burkholderia sp. (6RHB) in red soils, and Rhizobium sp. (4OLA, 5OLA, and 5OHA) in oxic soils. The ability to produce phytohormones was demonstrated in Microvirga ossetica when isolated from root nodules of Vicia alpestris [144]. The capacity of Burkholderia sp. and Rhizobium sp. to produce IAA was also well described in other studies [126]. Production of siderophores was only detected in isolates from red soils, namely Burkholderia sp. (5RHB) and C. zhejiangensis (4RHB). Siderophore producing bacteria may act as bioremediators and thus help plants to tolerate heavy metal stress (Al, Cd, Cu, Fe, Ga, In, Pb, and Zn) [29,145-149]. It was previously demonstrated that a heavy metal-resistant Burkholderia sp. isolate, which was able to produce siderophores and perform several other plant growth promoting activities, could also increase the uptake of $\mathrm{Pb}$ and $\mathrm{Cd}$ in tomato and maize plants growing in contaminated soil [150]. 
Additionally, siderophores may also act in biocontrol since they can reduce the proliferation of phytopathogens by preventing the acquisition of iron $[145,151]$. Only $V$. defluvii (10OHA) isolated from oxic soils showed cellulase activity (Table 2). Variovarax sp. is described as a useful source of hydrolytic enzymes [152]. This suggests the involvement of this species in the control of plant pathogens [153].

Table 2. Taxonomical identification of soil isolates from NSR soils and related phylum according to the most related source organism deposited in GenBank. Population codes follow Figure 1. GenBank accession numbers indicate the sequences generated in this study.

\begin{tabular}{|c|c|c|c|c|c|c|c|c|c|c|}
\hline $\begin{array}{l}\text { Soil } \\
\text { Type }\end{array}$ & $\begin{array}{c}\text { Fire } \\
\text { Frequency }\end{array}$ & Isolate & $\begin{array}{l}\text { Most Related 16S } \\
\text { rRNA Gene } \\
\text { Sequence }\end{array}$ & $\begin{array}{c}\text { GenBank } \\
\text { Accession } \\
\text { Number }\end{array}$ & $\begin{array}{c}\% \\
\text { Identity }\end{array}$ & $\begin{array}{l}\text { Growth in } \\
\text { N-Free } \\
\text { Media }\end{array}$ & $\begin{array}{c}\text { Phosphate } \\
\text { Solubilization }\end{array}$ & $\begin{array}{c}\text { Indole Acetic } \\
\text { Acid } \\
\text { Production } \\
(1)\end{array}$ & $\begin{array}{l}\text { Siderophore } \\
\text { Production }\end{array}$ & $\begin{array}{c}\text { Hydrolysis } \\
\text { of } \\
\text { Cellulose }\end{array}$ \\
\hline $\begin{array}{l}\text { Sandy } \\
\text { soils }\end{array}$ & Low & 10SLA & Microvirga sp. & MZ571264 & $96.54 \%$ & + & - & + & - & - \\
\hline \multirow{3}{*}{$\begin{array}{l}\text { Red } \\
\text { soils }\end{array}$} & \multirow{3}{*}{ High } & $4 \mathrm{RHB}$ & $\begin{array}{c}\text { Caballeronia } \\
\text { zhejiangensis strain } \\
\text { ND-B }\end{array}$ & MZ571257 & $96.90 \%$ & + & - & - & + & - \\
\hline & & $5 \mathrm{RHB}$ & Burkholderia sp. & MZ571258 & $96.27 \%$ & + & - & - & + & - \\
\hline & & $6 \mathrm{RHB}$ & $\begin{array}{l}\text { Burkholderia sp. } \\
\text { clone P4s-284 }\end{array}$ & MZ571259 & $72.58 \%$ & + & - & + & - & - \\
\hline \multirow{4}{*}{$\begin{array}{l}\text { Oxi- } \\
\text { soils }\end{array}$} & \multirow[b]{2}{*}{ Low } & 4OLA & $\begin{array}{c}\text { Rhizobium sp. } \\
\text { NA11036 }\end{array}$ & MZ571262 & $90.95 \%$ & + & - & + & - & - \\
\hline & & 5OLA & $\begin{array}{l}\text { Rhizobium altiplani } \\
\text { strain BR } 10423\end{array}$ & MZ571263 & $89.23 \%$ & + & - & + & - & - \\
\hline & \multirow{2}{*}{ High } & 5OHA & $\begin{array}{l}\text { Rhizobium sp. } \\
\text { isolate Moz93 }\end{array}$ & MZ571260 & $89.70 \%$ & + & - & + & - & - \\
\hline & & 10OHA & $\begin{array}{l}\text { Variovorax defluvii } \\
\text { strain } 2 \mathrm{C} 1-21\end{array}$ & MZ571261 & $97.88 \%$ & + & - & - & - & + \\
\hline
\end{tabular}

${ }^{1}$ Values greater than $5.0 \mu \mathrm{g} \mathrm{mL}{ }^{-1}$ IAA in the supernatant of cultures grown for $16 \mathrm{~h}$ in tryptophan-supplemented TY medium were considered positive.

\section{Conclusions}

The combination of next generation sequencing and culture dependent approaches allowed a comprehensive analysis of the bacterial diversity and associated functions in the rhizosphere of Brachystegia boehmii. The produced knowledge constitutes a significant contribution to the understanding of the dynamics of soil bacteria in tropical forest ecosystems, namely in plant-microbe interactions, and bioprospecting of new bacterial species. Although tropical ecosystems host ca. $80 \%$ of the global biodiversity, pressures imposed by a combination of human, animal, and climate pressure are inflicting major challenges. Thus, understanding key aspects of ecosystem dynamics is important to support community-based conservation programs.

The changes observed in the bacterial communities associated with the rhizosphere of B. boehmii are a consequence of a combined effect of soil type and fire regime. Nevertheless, independent of either factor, bacterial diversity was high, suggesting resiliency to extreme environments. The functional profiles of different bacterial consortia were consensual, safeguarding their main general functions. The most abundant taxonomic groups constituted novel sources of important traits, such as thermo- and halo-tolerance, production of biocompounds, and nutrient cycling. Several of these species may also represent new plant growth promoting bacteria (PGPB).

Similarly, the diversity of trapped bacteria in Vigna unguiculata was also dependent on soil type and fire frequency, and was considerably high, particularly when compared to other tropical legume trees. In all cases, the presence of diazotrophs (symbiotic: Mesorhizobium sp., Neorhizobium galegae, Rhizobium sp., and Ensifer adhaerens; and nonsymbiotic: Agrobacterium sp., Cohnella sp., Herbaspirillum huttiense, Pseudomonas sp., and Stenotrophomonas sp.) was evident. Consistent with these results, all soil isolates were also able to grow in a nitrogen-free medium and thus are possibly nitrogen-fixers, presenting cumulative PGP functions, such as IAA production (Microvirga sp., Burkholderia sp., and 
Rhizobium sp.), siderophore production (Burkholderia sp. and C. zhejiangensis), and plant protection abilities (Variovarax defluvii).

In conclusion, the rhizosphere of B. boehmii constitutes a source of promising bacteria in terms of plant-beneficial activities such as mobilization and acquisition of nutrients (nitrogen fixation, phosphorus production), mitigation of abiotic stress (bioremediation through siderophores), and modulation of plant hormone levels (and concomitant biocontrol and phytostimulation). Most bacteria belong to a group of newly identified species emerging from recent studies in recalcitrant environments and deserve special attention as they may constitute a new group of PGPB.

Supplementary Materials: The following are available online at https:/ /www.mdpi.com/article/10 .3390 /microorganisms9081562/s1, Figure S1: Rarefaction curves depicting the effect of sequencing on the number of operational taxonomic units within Miombo samples. S: sandy soils; R: red soils; $\mathrm{O}$ : oxi-soils of medium texture. Soil type code followed by $\mathrm{H}$ indicates high fire frequency and L indicates low fire frequency, Figure S2: The top PWY-378 MetaCyc pathway detected in Miombo samples and its relation to aerobic respiration I (cytochrome c). Table S1: Statistics of raw data of soil samples of Miombo woodlands. S: brownish-gray sandy soils; R: red soils of medium texture; $\mathrm{O}$ : red soils with medium texture oxic. Soil type code followed by $\mathrm{H}$ indicates high fire frequency while $\mathrm{L}$ indicates low fire frequency. Table S2: ANOVA results showing bacterial differences at the top Phyla between the type of soil (ST), the fire frequency (FI) and its interaction. Significant results are indicated in red. Table S3: ANOVA results showing bacterial differences at the top Genus between the type of soil type (ST), the fire frequency (FI) and its interaction. Significant results are indicated in red. Table S4: Top 20 pathways detected by PICRUSt in miombo samples. Table S5: Average dry weight (g) of Vigna unguiculata plants inoculated with different soil samples (mean \pm SD). S: brownish-gray sandy; R: red soils of medium texture; O: red soils of medium texture oxic; SL: Brachystegia rhizosphere on S with low fire frequency; SH: Brachystegia rhizosphere on S with high fire frequency; RL: Brachystegia rhizosphere on R with low fire frequency; RH: Brachystegia rhizosphere on R with high fire frequency; OL: Brachystegia rhizosphere on O with low fire frequency; $\mathrm{OH}$ : Brachystegia rhizosphere on $\mathrm{O}$ with high fire frequency. Uninoculated plants were also included supplied either with nitrogen (TN) or without mineral N (T0). Values of shoot dry weight are the average of replicates/soil type. Es (\%) was calculated as Es $=(\mathrm{Xs}-\mathrm{XT0} / \mathrm{XTN}-\mathrm{XT} 0) \times 100$, where $X \mathrm{X}$ represents the mean dry weight of inoculated shoots $\pm \mathrm{SD}$; XTN represents the mean dry weight of plants with nitrogen control; XT0 represents the mean dry weight of uninoculated plants. Table S6: Taxonomical identification of isolates from Vigna unguiculata root nodules inoculated with NSR soil samples and related phylum according to the most related source organism deposited in GenBank. Population codes follow Figure 1. GenBank accession numbers indicate the sequences generated in this study.

Author Contributions: Conceptualization: A.I.R.-B. and N.S.R.; lab work: I.S.A.M., P.F., I.V.e.C., R.S. and I.M.; field work: I.S.A.M., A.A.M., A.C. and N.S.R.; bioinformatic analysis: I.S.A.M., D.R.A.B., O.T.E. and I.M.; data validation: I.S.A.M., D.R.A.B., C.M., O.T.E., I.M. and A.I.R.-B.; formal analysis: all authors; investigation: all authors; resources: P.F., I.V.e.C., C.M., N.S.R. and A.I.R.-B.; data curation: I.S.A.M., I.M., A.I.R.-B. and N.S.R.; original draft preparation: I.S.A.M., I.M. and A.I.R.-B.; review and editing: all authors; visualization: A.C., I.S.A.M., D.R.A.B. and I.M.; supervision: C.M., N.S.R. and A.I.R.-B.; project administration and funding acquisition: N.S.R. and A.I.R.-B. All authors have read and agreed to the published version of the manuscript.

Funding: This work was supported by funds from Camões, Instituto da Cooperação e da Língua and Fundação para a Ciência e a Tecnologia through the research units UIDB/00239/2020 (CEF) and UIDB/00329/2020 (cE3c), the PhD grant SFRH/BD/113951/2015 (Ivete Sandra Maquia), the contribution Fundo Nacional de Investigação-Mozambique (FNI), and the Italian Cooperation for Development through Fundo para a Investigação Aplicada e Multissectorial (FIAM).

Institutional Review Board Statement: Not applicable.

Informed Consent Statement: Not applicable.

Data Availability Statement: The data presented in this study are available in the article and in the supplementary material. 
Acknowledgments: We thank Ana Maria Gomes from Instituto Superior Politécnico de Manica for the Vigna unguiculata seeds, Fernando Chanisso Mulandane from the Biotechnology Center, Eduardo Mondlane University, for drawing the map with the geographic locations of sampling points, Manuela Ferreira-Pinto for the help with the glycerol stocks, and the network of researchers from the Tropical College of ULisboa for the useful discussions.

Conflicts of Interest: The authors declare no conflict of interest.

\section{References}

1. Cardenas, E.; Kranabetter, J.M.; Hope, G.; Maas, K.R.; Hallam, S.; Mohn, W.W. Forest harvesting reduces the soil metagenomic potential for biomass decomposition. ISME J. 2015, 9, 2465-2476. [CrossRef] [PubMed]

2. Boyle, J.R.; Powers, R.F. Forest soils. In Reference Module in Earth Systems and Environmental Sciences; Elias, S.A., Ed.; Elsevier: Amsterdam, The Netherlands, 2013; pp. 1-11. [CrossRef]

3. Fierer, N.; Leff, J.W.; Adams, B.J.; Nielsen, U.N.; Bates, S.T.; Lauber, C.L.; Owens, S.; Gilbert, J.A.; Wall, D.H.; Caporaso, J.G. Cross-biome metagenomic analyses of soil microbial communities and their functional attributes. Proc. Natl. Acad. Sci. USA 2012, 109, 21390-21395. [CrossRef] [PubMed]

4. Neary, D.G.; Klopatek, C.C.; DeBano, L.F.; Ffolliott, P.F. Fire effects on belowground sustainability: A review and synthesis. For. Ecol. Manag. 1999, 122, 51-71. [CrossRef]

5. Kaur, R.; Rajesh, C.; Sharma, R.; Boparai, J.; Sharma, P. metagenomic investigation of bacterial diversity of hot spring soil from ecological genetics and genomics metagenomic investigation of bacterial diversity of hot spring soil from Manikaran, Himachal Pradesh, India. Ecol. Genet. Genom. 2018, 6, 16-21. [CrossRef]

6. Doran, J.W.; Zeiss, M.R. Soil Health and Sustainability: Managing the biotic component of soil quality. Appl. Soil Ecol. 2000, 15, 3-11. [CrossRef]

7. Waldrop, M.P.; Balser, T.C.; Firestone, M.K. Linking microbial community composition to function in a tropical soil. Soil Biol. Biochem. 2000, 32, 1837-1846. [CrossRef]

8. Yao, H.; He, Z.; Wilson, M.J.; Campbell, C.D. Microbial biomass and community structure in a sequence of soils with increasing fertility and changing land use. Microb. Ecol. 2000, 40, 223-237. [CrossRef]

9. Maquia, I.S.; Fareleira, P.; Castro, I.V.E.; Brito, D.R.A.; Soares, R.; Chaúque, A.; Ferreira-Pinto, M.M.; Lumini, E.; Berruti, A.; Ribeiro, N.S.; et al. Mining the microbiome of key species from african savanna woodlands: Potential for soil health improvement and plant growth promotion. Microorganisms 2020, 8, 1291. [CrossRef]

10. Macrae, A.; Coelho, R.R.R.; Peixoto, R.; Rosado, A.S. Tropical soil microbial communities. In The Prokaryotes: Prokaryotic Communities and Ecophysiology; Rosenberg, E., DeLong, E.F., Lory, S., Stackebrandt, E., Thompson, F., Eds.; Springer: Berlin/Heidelberg, Germany, 2013; pp. 85-95. [CrossRef]

11. Mittermeier, R.A.; Mittermeier, C.G.; Brooks, T.M.; Pilgrim, J.D.; Konstant, W.R.; da Fonseca, G.A.B.; Kormos, C. Wilderness and biodiversity conservation. Proc. Nat. Acad. Sci. USA 2003, 100, 10309-10313. [CrossRef]

12. Mittermeier, C.G.; Gil, P.R.; Mittermeier, R.; Fonseca, G.; Pilgrim, J. Wilderness: Earth's Last Wild Places, 1st ed.; Conservation International: Washington, DC, USA, 2002; p. 576.

13. Dziba, L.; Ramoelo, A.; Ryan, C.; Harrison, S.; Pritchard, R.; Tripathi, H.; Sitas, N.; Selomane, O.; Engelbrecht, F.; Pereira, L.; et al. Scenarios for Just and Sustainable Futures in the Miombo Woodlands. In Miombo Woodlands in a Changing Environment: Securing the Resilience and Sustainability of People and Woodlands; Ribeiro, N.S., Katerere, Y., Chirwa, P.W., Grundy, I.M., Eds.; Springer: Cham, Switzerland, 2020. [CrossRef]

14. Frost, P. The Ecology of Miombo Woodlands. In The Miombo in Transition: Woodlands and Welfare in Africa; Campbell, B.M., Ed.; Center for International Forestry Research (CIFOR): Bogor, Indonesia, 1996; pp. 11-57.

15. Ribeiro, N.S.; Katerere, Y.; Chirwa, P.W.; Grundy, I.M. (Eds.) Miombo Woodlands in a Changing Environment: Securing the Resilience and Sustainability of People and Woodlands; Springer: Cham, Switzerland, 2020; pp. 1-245. [CrossRef]

16. IPBES (Intergovernmental Science-Policy Platform on Biodiversity and Ecosystem Services). Summary for Policymakers of the Regional Assessment Report on Biodiversity and Ecosystem Services for Africa of the Intergovernmental Science-Policy Platform on Biodiversity and Ecosystem Services; IPBES Secretariat: Bonn, Germany, 2018; p. 49. Available online: https://ipbes.net/assessmentreports / africa (accessed on 12 July 2021).

17. IPBES. Global Assessment Report on Biodiversity and Ecosystem Service; IPBES Secretariat: Bonn, Germany, 2019; p. 1148. [CrossRef]

18. Gonçalves, F.M.P.; Revermann, R.; Gomes, A.L.; Aidar, M.P.M.; Finckh, M.; Juergens, N. Tree species diversity and composition of miombo woodlands in South-Central Angola: A chronosequence of forest recovery after shifting cultivation. Int. J. For. Res. 2017, 1-13. [CrossRef]

19. Dewees, P.A.; Campbell, B.M.; Katerere, Y.; Sitoe, A.; Cunningham, A.B.; Angelsen, A.; Wunder, S. Managing the miombo woodlands of Southern Africa: Policies, incentives and options for the rural poor. J. Nat. Resour. Policy Res. 2010, 2, 57-73. [CrossRef]

20. Malmer, A.; van Noordwijk, M.; Brujinzeel, L.A. Effects of shifting cultivation and forest fire. In Forest Water People in the Humid Tropics: Past Present and Future Hydrological Research for Integrated Land and Water Management; Bonell, M., Brujinzeel, L.A., Eds.; Cambridge University Press: Cambridge, UK, 2005. 
21. Bruijnzeel, L.A. Hydrology of moist tropical forests and effects of conversion: A state of knowledge review. J. Hydrol. 1991, 129, 397-399.

22. Higgins, S.I.; Bond, W.; February, E.C.; Bronn, A.; Euston-Brown, D.I.W.; Enslin, B.; Govender, N.; Rademan, L.; O’Regan, S.; Potgieter, A.L.F.; et al. Effects of four decades of fire manipulation on woody vegetation structure in savanna. Ecology 2007, 88, 1119-1125. [CrossRef] [PubMed]

23. Higgins, S.I.; Bond, W.J.; Trollope, W.S.W. Fire, resprouting and variability: A recipe for grass-tree coexistence in savanna. J. Ecol. 2000, 88, 213-229. [CrossRef]

24. Ribeiro, N.S.; Cangela, A.; Chauque, A.; Bandeira, R.R.; Ribeiro-Barros, A.I. Characterisation of spatial and temporal distribution of the fire regime in Niassa National Reserve, northern Mozambique. Int. J. Wildland Fire 2017, 26, 1021-1029. [CrossRef]

25. Saket, M. Tendencies of Forest Fires in Mozambique. Annex 4 to Proposal of a Model of Integrated Forest Management Plan for the Timber Concession of Maciambose Cheringoma, North of Sofala; República de Moçambique, Ministério da Agricultura e Pesca, Direcção Nacional de Florestas e Fauna Bravia ADB/ETC UK LTD: Beira, Mozambique, 1999.

26. Chidumayo, E.N. Species structure in zambian miombo woodland. J. Trop. Ecol. 1987, 3, 109-118. [CrossRef]

27. Mataix-Solera, J.; Guerrero, C.; García-Orenes, F.; Bárcenas, G.M.; Torres, M.P. Forest fire effects on soil microbiology. In Fire Effects on Soils and Restoration Strategies; Cerda, A., Robichaud, P., Eds.; Science Publisher: Oxford, UK, 2009; pp. 133-175.

28. Certini, G. Effects of fire on properties of forest soils: A review. Oecologia 2005, 143, 1-10. [CrossRef]

29. Frost, P.G.H.; Robertson, F. The Ecological Effects of Fire in Savannas. In Determinants of Tropical Savannas; Walker, B.H., Ed.; IRL Press: Oxford, UK; Harare, Zimbabwe, 1985; pp. 93-140.

30. Ahemad, M.; Kibret, M. Mechanisms and applications of plant growth promoting rhizobacteria: Current perspective. J. King Saud Univ. Sci. 2014, 26, 1-20. [CrossRef]

31. Somers, E.; Vanderleyden, J.; Srinivasan, M. Rhizosphere bacterial signalling: A love parade beneath our feet. Crit. Rev. Microbiol. 2004, 30, 205-240. [CrossRef]

32. Ganzin, N.; Poilecot, P.; Prin, T. Vegetation Survey of Niassa National Reserve Oriented for Vegetation Mapping and Range Resources Assessment Using Satellite Imagery. 2010. Available online: https:/ /www.biofund.org.mz/wp-content/uploads/2019 /01/1548766114-F0821.Mission_report_Niassa_Nganzin_Ppoilecot_june2010_final.pdf (accessed on 12 July 2021).

33. Ribeiro, N.S.; Matos, C.N.; Moura, I.R.; Washington-Allen, R.A.; Ribeiro, A.I. Monitoring vegetation dynamics and carbon stock density in miombo woodlands. Carbon Balance Manag. 2013, 8, 11. [CrossRef] [PubMed]

34. Ribeiro, N.S.; Shugart, H.H.; Washington-Allen, R. The effects of fire and elephants on species composition and structure of the Niassa Reserve, northern Mozambique. For. Ecol. Manag. 2008, 255, 1626-1636. [CrossRef]

35. Craig, G.C. Aerial Survey of Wildlife in the Niassa Reserve and Adjacent Areas; Technical Report; Sociedade de Gestão e Desenvolvimento da Reserva do Niassa (SGDRN): Maputo, Mozambique, 2009.

36. Riley, D.; Barber, S.A. Salt accumulation at the soybean (Glycine max. (L.) Merr.) root-soil interface. Soil. Sci. Soc. Am. J. 1970, 34, 154-155. [CrossRef]

37. Rognes, T.; Flouri, T.; Nichols, B.; Quince, C.; Mahé, F. VSEARCH: A Versatile Open Source Tool for Metagenomics. PeerJ 2016, 4, e2584. [CrossRef] [PubMed]

38. López-García, A.; Pineda-Quiroga, C.; Atxaerandio, R.; Pérez, A.; Hernández, I.; García-Rodríguez, A.; González-Recio, O. Comparison of Mothur and QIIME for the analysis of rumen microbiota composition based on 16S rRNA amplicon sequences. Front. Microbiol. 2018, 9. [CrossRef] [PubMed]

39. Magoč, T.; Salzberg, S.L. FLASH: Fast Length Adjustment of Short Reads to improve genome assemblies. Bioinformatics 2011, 27, 2957-2963. [CrossRef] [PubMed]

40. Edgar, R.C.; Haas, B.J.; Clemente, J.C.; Quince, C.; Knight, R. uchime improves sensitivity and speed of chimera detection. Bioinformatics 2011, 27, 2194-2200. [CrossRef]

41. DeSantis, T.Z.; Hugenholtz, P.; Larsen, N.; Rojas, M.; Brodie, E.L.; Keller, K.; Huber, T.; Dalevi, D.; Hu, P.; Andersen, G.L. Greengenes, a chimera-checked $16 \mathrm{~S}$ rRNA gene database and workbench compatible with ARB. Appl. Environ. Microbiol. 2006, 72, 5069-5072. [CrossRef]

42. Lozupone, C.A.; Knight, R. UniFrac: A new phylogenetic method for comparing microbial communities. Appl. Environ. Microbiol. 2005, 71, 8228-8235. [CrossRef]

43. Statistica (Data Analysis Software System); Release 13; StataCorp LP: College Station, TX, USA, 2013.

44. Segata, N.; Izard, J.; Waldron, L.; Gevers, D.; Miropolsky, L.; Garrett, W.S.; Huttenhower, C. Metagenomic biomarker discovery and explanation. Genome Biol. 2011, 12, R60. [CrossRef]

45. Asnicar, F.; Weingart, G.; Tickle, T.L.; Huttenhower, C.; Segata, N. Compact graphical representation of phylogenetic data and metadata with GraPhlAn. PeerJ 2015, 3, e1029. [CrossRef]

46. Douglas, G.M.; Maffei, V.J.; Zaneveld, J.; Svetlana, Y.N.; Brown, J.R.; Taylor, C.M.; Hutternhower, C.; Langille, M.G.I. PICRUSt2: An improved and customizable approach for metagenome inference. BioRxiv Prepr. 2020. [CrossRef]

47. Louca, S.; Doebeli, M. Efficient comparative phylogenetics on large trees. Bioinformatics 2018, 34, 1053-1055. [CrossRef] [PubMed]

48. Ye, Y.; Doak, T.G. A Parsimony approach to biological pathway reconstruction/inference for genomes and metagenomes. PLoS Comput. Biol. 2009, 5, e1000465. [CrossRef]

49. Caspi, R.; Billington, R.; Fulcher, C.A.; Keseler, I.M.; Kothari, A.; Krummenacker, M.; Latendresse, M.; Midford, P.E.; Ong, Q.; Ong, W.K.; et al. The MetaCyc database of metabolic pathways and enzymes. Nucleic Acids Res. 2019, 48, D445-D453. [CrossRef] 
50. Parks, D.H.; Tyson, G.W.; Hugenholtz, P.; Beiko, R.G. STAMP: Statistical Analysis of Taxonomic and Functional Profiles. Bioinformatics 2014, 30, 3123-3124. [CrossRef] [PubMed]

51. Bluman, A. Elementary Statistics: A Step by Step Approach; McGraw-Hill Companies: New York, NY, USA, 2007. [CrossRef]

52. Benjamini, Y.; Hochberg, Y. Controlling the false discovery rate: A practical and powerful approach to multiple testing. J. R. Stat. Soc. Ser. B (Methodol.) 1995, 57, 289-300. [CrossRef]

53. Gomes, A.M.F.; Draper, D.; Talhinhas, P.; Santos, P.B.; Simões, F.; Nhantumbo, N.; Massinga, R.; Ramalho, J.C.; Marques, I.; Ribeiro-Barros, A.I. Genetic diversity among cowpea (Vigna unguiculata (L.) Walp.) landraces suggests central Mozambique as an important hotspot of variation. Agronomy 2020, 10, 1893. [CrossRef]

54. Gomes, A.M.F.; Draper, D.; Nhantumbo, N.; Massinga, R.; Ramalho, J.C.; Marques, I.; Ribeiro-Barros, A.I. Diversity of cowpea Vigna unguiculata (L.) Walp. landraces in Mozambique: New opportunities for crop improvement and future breeding programs. Agronomy 2021, 11, 991. [CrossRef]

55. Jensen, H.L. Nitrogen fixation in leguminous plants. I. General characters of root-nodule bacteria isolated from species of Medicago and Trifolium in Australia. Proc. Linn. Soc. NSW 1942, 66, 98-108. Available online: http://biostor.org/reference/68107 (accessed on 12 July 2021).

56. Ferreira, E.M.; Marques, J.F. Selection of portuguese Rhizobium leguminosarum bv. trifolii strains for production of legume inoculants. Plant Soil 1992, 147, 151-158. [CrossRef]

57. Vincent, J.M. A Manual for the Practical Study of Root-Nodule Bacteria, I.B.P. Handbook; Blackwell Scientific Publisher: Oxford, UK, 1970; Volume 8, pp. 8-9.

58. Beringer, J.E. R Factor transfer in Rhizobium leguminosarum. J. Gen. Microbiol. 1974, 84, 188-198. [CrossRef] [PubMed]

59. Burk, D.; Lineweaver, H. The influence of fixed nitrogen on azotobacter. J. Bacteriol. 1930, 19, 389-414. [CrossRef] [PubMed]

60. Castanheira, N.; Dourado, A.C.; Alves, P.I.; Cortés-Pallero, A.M.; Delgado-Rodríguez, A.I.; Prazeres, A.; Borges, N.; Sánchez, C.; Crespo, M.T.B.; Fareleira, P. Annual ryegrass-associated bacteria with potential for plant growth promotion. Microbiol. Res. 2014, 169, 768-779. [CrossRef] [PubMed]

61. Asghar, H.N.; Zahir, Z.A.; Arshad, M.; Khaliq, A. Relationship between in vitro production of auxins by rhizobacteria and their growth-promoting activities in Brassica juncea L. Biol. Fertil. Soils 2002, 35, 231-237. [CrossRef]

62. Schwyn, B.; Neilands, J.B. Universal chemical assay for the detection and determination of siderophores. Anal. Biochem. 1987, 160, 47-56. [CrossRef]

63. Pérez-Miranda, S.; Cabirol, N.; George-Téllez, R.; Zamudio-Rivera, L.S.; Fernández, F.J. O-CAS, a fast and universal method for siderophore detection. J. Microbiol. Methods 2007, 70, 127-131. [CrossRef] [PubMed]

64. Peix, A.; Rivas-Boyero, A.A.; Mateos, P.F.; Rodriguez-Barrueco, C.; Martínez-Molina, E.; Velazquez, E. Growth promotion of chickpea and barley by a phosphate solubilizing strain of mesorhizobium mediterraneum under growth chamber conditions. Soil. Biol. Biochem. 2001, 33, 103-110. [CrossRef]

65. Verma, S.C.; Ladha, J.K.; Tripathi, A.K. Evaluation of plant growth promoting and colonization ability of endophytic diazotrophs from deep water rice. J. Biotechnol. 2001, 91, 127-141. [CrossRef]

66. Reinhold-Hurek, B.; Hurek, T.; Claeyssens, M.; Montagu, M.V. Cloning, expression in Escherichia coli, and characterization of cellulolytic enzymes of Azoarcus sp., a root-invading diazotroph. J. Bacteriol. Res. 1993, 175, 7056-7065. [CrossRef]

67. Mateos, P.F.; Jimenez-Zurdo, J.I.; Chen, J.; Squartini, A.S.; Haack, S.K.; Martinez- Molina, E.; Hubbell, D.H.; Dazzo, F.B. Cellassociated pectinolytic and cellulolytic enzymes in Rhizobium leguminosarum biovar trifolii. Appl. Environ. Microbiol. 1992, 58, 1816-1822. [CrossRef]

68. Villadas, P.J.; Díaz-Díaz, S.; Rodríguez-Rodríguez, A.; del Arco-Aguilar, M.; Fernández-González, A.J.; Pérez-Yépez, J.; Arbelo, C.; González-Mancebo, J.M.; Fernández-López, M.; León-Barrios, M. The soil microbiome of the laurel forest in Garajonay National Park (La Gomera, Canary Islands): Comparing unburned and burned habitats after a wildfire. Forests 2019, 10, 1051. [CrossRef]

69. Rodríguez, J.; González-Pérez, J.A.; Turmero, A.; Hernández, M.; Ball, A.S.; González-Vila, F.J.; Arias, M.E. Physico-chemical and microbial perturbations of andalusian pine forest soils following a wildfire. Sci. Total Environ. 2018, 634, 650-660. [CrossRef] [PubMed]

70. Hamman, S.T.; Burke, I.C.; Stromberger, M.E. Relationships between microbial community structure and soil environmental conditions in a recently burned system. Soil. Biol. Biochem. 2007, 39, 1703-1711. [CrossRef]

71. Frost, P.G.H. The responses and survival of organisms in fire-prone environments. In Ecological Effects of Fire in South African Ecosystems; Booysen, P.V., Tainton, N.M., Eds.; Springer: Berlin/Heidelberg, Germany, 1984; pp. 273-309.

72. Maquia, I.; Ribeiro, N.S.; Silva, V.; Bessa, F.; Goulao, L.F.; Ribeiro, A.I. Genetic diversity of Brachystegia boehmii Taub. and Burkea africana Hook. f. across a fire gradient in Niassa National Reserve, northern Mozambique. Biochem. Syst. Ecol. 2013, 48, $238-247$. [CrossRef]

73. Parr, C.L.; Andersen, A.N. Patch mosaic burning for biodiversity conservation: A critique of the pyrodiversity paradigm. Conserv. Biol. 2006, 20, 1610-1619. [CrossRef]

74. Kara, O.; Bolat, I. Short-term effects of wildfire on microbial biomass and abundance in black pine plantation soils in Turkey. Ecol. Indic. 2009, 9, 1151-1155. [CrossRef]

75. Janzen, C.; Tobin-Janzen, T. Microbial communities in fire-affected soils. In Microbiology of Extreme Soils; Dion, P., Nautiyal, C.S., Eds.; Springer: Berlin/Heidelberg, Germany, 2008; pp. 299-316. [CrossRef] 
76. Liang, C.; Ding, Y.; Yue, Y.; Zhang, X.Y.; Song, M.H.; Gao, J.Q.; Yu, F.H. Litter affects CO2 emission from Alpine wetland soils experiencing drying-rewetting cycles with different intensities and frequencies. Catena 2020. [CrossRef]

77. Fernández-González, A.J.; Martínez-Hidalgo, P.; Cobo-Díaz, J.F.; Villadas, P.J.; Martínez-Molina, E.; Toro, N.; Tringe, S.G.; Fernández-López, M. The rhizosphere microbiome of burned holm-oak: Potential role of the genus arthrobacter in the recovery of burned soils. Sci. Rep. 2017, 7, 6008. [CrossRef]

78. Jacoby, R.; Peukert, M.; Succurro, A.; Koprivova, A.; Kopriva, S. The role of soil microorganisms in plant mineral nutritionCurrent knowledge and future directions. Front. Plant Sci. 2017, 8, 1617. [CrossRef]

79. Bulgarelli, D.; Schlaeppi, K.; Spaepen, S.; Van Themaat, E.; Ver, L.; Schulze-Lefert, P. Structure and functions of the bacterial microbiota of plants. Annu. Rev. Plant Biol. 2013, 64, 807-838. [CrossRef]

80. Severino, R.; Froufe, H.J.C.; Barroso, C.; Albuquerque, L.; Lobo-da-Cunha, A.; da Costa, M.S.; Egas, C. High-quality draft genome sequence of Gaiella occulta isolated from a $150 \mathrm{~m}$ deep mineral water borehole and comparison with the genome sequences of other deep-branching lineages of the phylum Actinobacteria. Microbiologyopen 2019, e840. [CrossRef]

81. Egas, C.; Barroso, C.; Froufe, H.J.C.; Pacheco, J.; Albuquerque, L.; Costa, M.S. Complete genome sequence of the radiation-resistant bacterium Rubrobacter radiotolerans RSPS-4. Stand. Genom. Sci. 2014, 9, 1062-1075. [CrossRef] [PubMed]

82. Mun, C.L.; Ling, C.M.W.V. Effects of elevated temperature on the tropical soil bacterial diversity. Sains Malays. 2020, 49, 2335-2344. [CrossRef]

83. Parente, C.E.T.; Brito, E.M.S.; Carreta, C.A.; Cervantes-Rodríguez, E.A.; Fábila-Canto, A.P.; Vollú, R.E.; Seldin, L.; Malm, O. Bacterial diversity changes in agricultural soils influenced by poultry litter fertilization. Braz. J. Microbiol. 2021, 52, 675-686. [CrossRef] [PubMed]

84. León, A.; Del-Ángel, M.; Ávila, J.L.; Delgado, G. Phthalides: Distribution in nature, chemical reactivity, synthesis, and biological activity. Prog. Chem. Org. Nat. Prod. 2017, 104. [CrossRef]

85. Pertile, M.; Sousa, R.M.S.; Mendes, L.W.; Antunes, J.E.L.; Oliveira, L.M.S.; Araujo, F.F.; Melo, V.M.M.; Araujo, A.S.F. Response of soil bacterial communities to the application of the herbicides imazethapyr and flumyzin. Eur. J. Soil Biol. 2021, $102,103252$. [CrossRef]

86. Zhang, B.; Wu, X.; Tai, X.; Sun, L.; Wu, M.; Zhang, W.; Chen, X.; Zhang, G.; Chen, T.; Liu, G.; et al. Variation in actinobacterial community composition and potential function in different soil ecosystems belonging to the arid heihe river basin of northwest China. Front. Microbiol. 2019, 10, 2209. [CrossRef]

87. Kant, R.; Van Passel, M.W.J.; Palva, A.; Lucas, S.; Lapidus, A.; Del Rio, T.G.; Dalin, E.; Tice, H.; Bruce, D.; Goodwin, L.; et al. Genome sequence of Chthoniobacter flavus ellin428, an aerobic heterotrophic soil bacterium. J. Bacteriol. Res. 2011, 193, 2902-2903. [CrossRef]

88. Sangwan, P.; Chen, X.; Hugenholtz, P.; Janssen, P.H. Chthoniobacter flavus gen. nov., sp. nov., the first pure-culture representative of subdivision two, Spartobacteria classis nov., of the phylum Verrucomicrobia. Appl. Environ. Microbiol. 2004, 70, 5857-5881. [CrossRef] [PubMed]

89. Herlemann, D.P.R.; Lundin, D.; Labrenz, M.; Jürgens, K.; Zheng, Z.; Aspeborg, H.; Andersson, A.F. Metagenomic De Novo assembly of an aquatic representative of the verrucomicrobial class Spartobacteria. MBio 2013, 4, e0569-12. [CrossRef]

90. Wüst, P.K.; Foesel, B.U.; Geppert, A.; Huber, K.J.; Luckner, M.; Wanner, G.; Overmann, J. Brevitalea aridisoli, B. deliciosa and Arenimicrobium luteum, three novel species of Acidobacteria subdivision 4 (class Blastocatellia) isolated from savanna soil and description of the novel family PyrinomonadaceaeInt. J. Syst. Evol. Microbiol. 2016, 66, 3355-3366. [CrossRef]

91. Jia, D.; Dong, X.; Li, Y. Effect of strip harvesting on bacterial diversity of forest soils in the Daxing'an mountains. Soil Sci. Soc. Am. J. 2020, 84, 512-521. [CrossRef]

92. Armbruster, M.; Goodall, T.; Hirsch, P.R.; Ostle, N.; Puissant, J.; Fagan, K.C.; Pywell, R.F.; Griffiths, R.I. Bacterial and archaeal taxa are reliable indicators of soil restoration across distributed calcareous grasslands. Eur. J. Soil Sci. 2020, 1-15. [CrossRef]

93. Aguiar, L.M.; Souza, M.F.; Laia, M.L.; Melo, J.O.; Costa, M.R.; Gonçalves, J.F.; Silva, D.V.; Santos, J.B. Metagenomic analysis reveals mechanisms of atrazine biodegradation promoted by tree species. Environ. Pollut. 2020, 267, 115636. [CrossRef] [PubMed]

94. Song, L.; Niu, X.; Tian, Y.; Xiao, Y. Assessment of PAH degradation potential of native species from a coking plant through identifying of the beneficial bacterial community within the rhizosphere soil. Chemosphere 2021, 264, 128513. [CrossRef]

95. Zhang, C.; Tayyab, M.; Abubakar, A.Y.; Yang, Z.; Pang, Z.; Islam, W.; Lin, Z.; Li, S.; Luo, J.; Fan, X.; et al. Bacteria with different assemblages in the soil profile drive the diverse nutrient cycles in the sugarcane straw retention ecosystem. Diversity 2019, 11, 194. [CrossRef]

96. Too, C.C.; Keller, A.; Sickel, W.; Lee, S.M.; Yule, C.M. microbial community structure in a Malaysian tropical peat swamp forest: The influence of tree species and depth. Front. Microbiol. 2018, 9, 2859. [CrossRef] [PubMed]

97. Tatar, D. Isolation, phylogenetic analysis and antimicrobial activity of halophilic actinomycetes from different saline environments located near Çorum Province. Biologia 2021. [CrossRef]

98. Messaoudi, O.; Wink, J.; Bendahou, M. Diversity of actinobacteria isolated from date palms rhizosphere and saline environments: Isolation, identification and biological activity evaluation. Microorganisms 2020, 8, 1853. [CrossRef]

99. Falagán, C.; Johnson, D.B. Acidibacter ferrireducens gen. nov., sp. nov.: An acidophilic ferric iron-reducing Gammaproteobacterium. Extremophiles 2014, 18, 1067-1073. [CrossRef] [PubMed] 
100. García-Fraile, P.; Benada, O.; Cajthaml, T.; Baldrian, P.; Lladó, S. Terracidiphilus gabretensis gen. nov., sp. nov., an abundant and active forest soil acidobacterium important in organic matter transformation. Appl. Environ. Microbiol. 2016, 82, 560-569. [CrossRef] [PubMed]

101. Liu, J.; He, X.; Sun, J.; Ma, Y. A degeneration gradient of poplar trees contributes to the taxonomic, functional, and resistome diversity of bacterial communities in rhizosphere soils. Int. J. Mol. Sci. 2021, 22. [CrossRef]

102. Blum, J.S.; Kulp, T.R.; Han, S.; Lanoil, B.; Saltikov, C.W.; Stolz, J.F.; Miller, L.G.; Oremland, R.S. Desulfohalophilus alkaliarsenatis gen. nov., sp. nov., an extremely halophilic sulfate- and arsenate-respiring bacterium from Searles Lake, California. Extremophiles 2012, 16, 727-742. [CrossRef]

103. Hemmat-Jou, M.H.; Safari-Sinegani, A.A.; Mirzaie-Asl, A.; Tahmourespour, A. Analysis of microbial communities in heavy metals-contaminated soils using the metagenomic approach. Ecotoxicology 2018, 27, 1281-1291. [CrossRef] [PubMed]

104. Xin, X.; Qiu, W. Linking microbial mechanism with bioelectricity production in sludge matrix-fed microbial fuel cells: Freezing/thawing liquid versus fermentation liquor. Sci. Total Environ. 2021, 752, 141907. [CrossRef]

105. Dias, M.A.M.; Bomfim, C.S.G.; Rodrigues, D.R.; Silva, A.F.; Santos, J.C.S.; Nascimento, T.R.; Martins, L.M.V. Paraburkholderia spp are the main rhizobial microsymbionts of Mimosa tenuiflora (Willd.) Poir. in soils of the Brazilian tropical dry forests (Caatinga biome). Syst. Appl. Microbiol. 2021, 44, 126208. [CrossRef] [PubMed]

106. Alhadrami, H.A.; Thissera, B.; Hassan, M.H.A.; Behery, F.A.; Ngwa, C.J.; Hassan, H.M.; Pradel, G.; Abdelmohsen, U.R.; Rateb, M.E. Bio-guided isolation of antimalarial metabolites from the coculture of two red sea sponge-derived actinokineospora and Rhodococcus spp. Mar. Drugs 2021, 19, 109. [CrossRef]

107. Arn, F.; Frasson, D.; Kroslakova, I.; Rezzonico, F.; Pothie, J.F.; Riedl, R.; Sievers, M. Isolation and identification of actinomycetes strains from Switzerland and their biotechnological potential. Chimia (Aarau) 2020, 74, 382-390. [CrossRef] [PubMed]

108. Oberhofer, M.; Hess, J.; Leutgeb, M.; Gössnitzer, F.; Rattei, T.; Wawrosch, C.; Zotchev, S.B. Exploring Actinobacteria associated with rhizosphere and endosphere of the native alpine medicinal plant Leontopodium nivale subspecies alpinum. Front. Microbiol. 2019, 10, 1-13. [CrossRef]

109. Heidari, B.; Mohammadipanah, F. Isolation and identification of two alkaloid structures with radical scavenging activity from Actinokineospora sp. UTMC 968, a new promising source of alkaloid compounds. Mol. Biol. Rep. 2018, 45, 2325-2332. [CrossRef]

110. Ivanova, A.A.; Philippov, D.A.; Kulichevskaya, I.S.; Dedysh, S.N. Distinct diversity patterns of Planctomycetes associated with the freshwater macrophyte Nuphar lutea (L.) Smith. Antonie Leeuwenhoek Int. J. Gen. Mol. Microbiol. 2017, 111, 811-823. [CrossRef] [PubMed]

111. Jroundi, F.; Martinez-Ruiz, F.; Merroun, M.L.; Gonzalez-Muñoz, M.T. Exploring bacterial community composition in Mediterranean deep-sea sediments and their role in heavy metal accumulation. Sci. Total Environ. 2020, 712, 135660. [CrossRef]

112. Fan, M.; Li, J.; Tang, Z.; Shangguan, Z. Soil bacterial community succession during desertification in a desert steppe ecosystem. L. Degrad. Dev. 2020, 31, 1662-1674. [CrossRef]

113. Nagkirti, P.D.; Engineer, A.S.; Dhakephalkar, P.K. Xylanimonas oleitrophica sp. nov., a novel petroleum hydrocarbon degrading bacterium isolated from an Indian oil reservoir. Antonie Leeuwenhoek Int. J. Gen. Mol. Microbiol. 2021, 114, 129-136. [CrossRef]

114. Moe, L.A. Amino acids in the rhizosphere: From plants to microbes. Am. J. Bot. 2013, 100, 1692-1705. [CrossRef] [PubMed]

115. Auffret, M.D.; Karhu, K.; Khachane, A.; Dungait, J.; Fraser, F.; Hopkins, D.; Wookey, P.; Singh, B.; Freitag, T.E.; Hartley, I.P.; et al. The role of microbial community composition in controlling soil respiration responses to temperature. PLoS ONE 2016, 11, e0165448. [CrossRef]

116. Zheng, Y.; Liang, J.; Zhao, D.L.; Meng, C.; Xu, Z.C.; Xie, Z.H.; Zhang, C.S. The root nodule microbiome of cultivated and wild halophytic legumes showed similar diversity but distinct community structure in yellow river delta saline soils. Microorganisms 2020, 8, 207. [CrossRef] [PubMed]

117. Meyer, S.E.D.; Beuf, K.D.; Vekeman, B.; Willems, A. A large diversity of non-rhizobial endophytes found in legume root nodules in Flanders (Belgium). Soil Biol. Biochem. 2015, 83, 1-11. [CrossRef]

118. Muresu, R.; Polone, E.; Sulas, L.; Baldan, B.; Tondello, A.; Delogu, G.; Cappuccinelli, P.; Alberghini, S.; Benhizia, Y.; Benhizia, H.; et al. Coexistence of predominantly nonculturable rhizobia with diverse, endophytic bacterial taxa within nodules of wild legumes. FEMS Microbiol. Ecol. 2008, 63, 383-400. [CrossRef]

119. Kan, F.L.; Chen, Z.Y.; Wang, E.T.; Tian, C.F.; Sui, X.H.; Chen, W.X. Characterization of symbiotic and endophytic bacteria isolated from root nodules of herbaceous legumes grown in Qinghai-Tibet plateau and in other zones of China. Arch. Microbiol. 2007, 188, 103-115. [CrossRef] [PubMed]

120. Messiha, N.A.S.; van Diepeningen, A.D.; Farag, N.S.; Abdallah, S.A.; Janse, J.D.; van Bruggen, A.H.C. Stenotrophomonas maltophilia: A new potential biocontrol agent of Ralstonia solanacearum, causal agent of potato brown rot. Eur. J. Plant Pathol. 2007, 118, 211-225. [CrossRef]

121. Mukherjee, P.; Roy, P. Genomic potential of Stenotrophomonas maltophilia in bioremediation with an assessment of its multifaceted role in our environment. Front. Microbiol. 2016, 7, 967. [CrossRef]

122. Berg, G.; Marten, P.; Ballin, G. Stenotrophomonas maltophilia in the rhizosphere of oilseed rape-occurrence, characterization and interaction with phytopathogenic fungi. Microbiol. Res. 1996, 151, 19-27. [CrossRef]

123. Gopi, K.; Jinal, H.N.; Prittesh, P.; Kartik, V.P.; Amaresan, N. Effect of copper-resistant Stenotrophomonas maltophilia on Maize (Zea mays) growth, physiological properties, and copper accumulation: Potential for phytoremediation into biofortification. Int. J. Phytoremed. 2020. [CrossRef] [PubMed] 
124. An, S.Q.; Berg, G. Stenotrophomonas maltophilia. Trends Microbiol. 2018. [CrossRef]

125. Naz, I.; Bano, A. Assessment of phytohormones producing capacity of Stenotrophomonas maltophilia ssa and its interaction with Zea Mays L. Pak. J. Bot. 2012, 44, 465-469.

126. Spaepen, S.; Vanderleyden, J.; Remans, R. Indole-3-acetic acid in microbial and microorganism-plant signaling. FEMS Microbiol. Rev. 2007, 31, 425-448. [CrossRef]

127. Hwang, H.; Yu, M.; Lai, E.-M. Agrobacterium-Mediated plant transformation: Biology and applications. Arab. Book 2017, 15. [CrossRef]

128. Krenek, P.; Samajova, O.; Luptovciak, I.; Doskocilova, A.; Komis, G.; Samaj, J. Transient plant transformation mediated by Agrobacterium tumefaciens: Principles, methods and applications. Biotechnol. Adv. 2015, 1, 1024-1042. [CrossRef]

129. Veena, V.; Taylor, C.G. Agrobacterium rhizogenes: Recent developments and promising applications. Vitr. Cell. Dev. Biol. Plant 2007, 43, 83-403. [CrossRef]

130. Rogel, M.A.; Hernández-Lucas, I.; Kuykendall, L.D.; Balkwill Martinez-Romero, E. Nitrogen-fixing nodules with Ensifer adhaerens harboring Rhizobium tropici symbiotic plasmids. Appl. Environ. Microbiol. 2001, 67, 3264-3268. [CrossRef]

131. Doyle, J.J. Phylogenetic perspectives on nodulation: Evolving views of plants and symbiotic bacteria. Trends Plant Sci. 1998, 3 , 473-478. [CrossRef]

132. Teixeira, H.; Rodríguez-Echeverría, S. Identification of symbiotic nitrogen-fixing bacteria from three african leguminous trees in Gorongosa National Park. Syst. Appl. Microbiol. 2016, 39, 350-358. [CrossRef]

133. Dharni, S.; Srivastava, A.K.; Samad, A.; Patra, D.D. Impact of plant growth promoting Pseudomonas monteilii psf84 and Pseudomonas plecoglossicida psf610 on metal uptake and production of secondary metabolite (monoterpenes) by rose-scented geranium (Pelargonium graveolenscv. bourbon) grown on tannery sludge. Chemosphere 2014, 117, 433-439. [CrossRef] [PubMed]

134. Trinh, C.S.; Lee, H.; Lee, W.J.; Lee, S.J.; Chung, N.; Han, J.; Kim, J.; Hong, S.W.; Lee, H. Evaluation of the plant growth-promoting activity of Pseudomonas nitroreducens in Arabidopsis thaliana and Lactuca sativa. Plant Cell. Rep. 2018, 37, 873-885. [CrossRef]

135. Natsagdorj, O.; Sakamoto, H.; Santiago, D.M.O.; Santiago, C.D.; Orikasa, Y.; Okazaki, K.; Ikeda, S.; Ohwada, T. Variovorax sp. has an optimum cell density to fully function as a plant growth promoter. Microorganisms 2019, 7, 82. [CrossRef]

136. Gupta, S.; Pandey, S. ACC deaminase producing bacteria with multifarious plant growth promoting traits alleviates salinity stress in french bean (Phaseolus vulgaris) plants. Front. Microbiol. 2019, 10, 1506. [CrossRef] [PubMed]

137. Lang, J.M.; Pérez-Quintero, A.L.; Koebnik, R.; DuCharme, E.; Sarra, S.; Doucoure, H.; Keita, I.; Ziegle, J.; Jacobs, J.M.; Olivia, R.; et al. A Pathovar of Xanthomonas oryzae infecting wild grasses provides insight into the evolution of pathogenicity in rice agroecosystems. Front. Plant Sci. 2019, 10, 507. [CrossRef] [PubMed]

138. Takeda, M.; Suzuki, I.; Koizumi, J.I. Balneomonas flocculans gen. nov., sp. nov., a new cellulose-producing member of the $\alpha-2$ subclass of Proteobacteria. Syst. Appl. Microbiol. 2004, 27, 139-145. [CrossRef] [PubMed]

139. Ardley, J.K.; Parker, M.A.; De Meyer, S.E.; Trengove, R.D.; O’Hara, G.W.; Reeve, W.G.; Yates, R.J.; Dilworth, M.J.; Willems, A.; Howieson, J.G. Microvirga lupini sp. nov., Microvirga lotononidis sp. nov. and Microvirga zambiensis sp. nov. are alphaproteobacterial root-nodule bacteria that specifically nodulate and fix nitrogen with geographically and taxonomically separate legume hosts. Int. J. Syst. Evol. Microbiol. 2012, 62, 2579-2588. [CrossRef]

140. Vial, L.; Chapalain, A.; Groleau, M.C.; Déziel, E. The various lifestyles of the Burkholderia cepacia complex species: A tribute to adaptation. Environ. Microbiol. 2011, 13, 1-12. [CrossRef] [PubMed]

141. Belimov, A.A.; Dodd, I.C.; Hontzeas, N.; Theobald, J.C.; Safronova, V.I.; Davies, W.J. Rhizosphere Bacteria Containing 1Aminocyclopropane-1-Carboxylate Deaminase Increase yield of plants grown in drying soil via both local and systemic hormone signalling. New Phytol. 2009, 181, 413-423. [CrossRef]

142. Hamdi Hussein, Z. Rhizobia from wild legumes: Diversity, taxonomy, ecology, nitrogen fixation and biotechnology. J. Biotechnol. 2001, 91, 143-153.

143. Estrada-De Los Santos, P.; Bustillos-Cristales, R.; Caballero-Mellado, J. Burkholderia, a genus rich in plant-associated nitrogen fixers with wide environmental and geographic distribution. Appl. Environ. Microbiol. 2001, 67, 2790-2798. [CrossRef] [PubMed]

144. Safronova, V.I.; Kuznetsova, I.G.; Sazanova, A.L.; Belimov, A.A.; Andronov, E.E.; Chirak, E.R.; Osledkin, Y.S.; Onishchuk, O.P.; Kurchak, O.N.; Shaposhnikov, A.I.; et al. Microvirga ossetica sp. nov., a species of rhizobia isolated from root nodules of the legume species Vicia alpestris Steven. Int. J. Syst. Evol. Microbiol. 2017, 67, 94-100. [CrossRef] [PubMed]

145. Glick, B.R. Plant growth-promoting bacteria: Mechanisms and applications. Hindawi Publ. Corp. Sci. 2012, $2020,963401$. [CrossRef]

146. Braud, A.; Jézéquel, K.; Vieille, E.; Tritter, A.; Lebeau, T. Changes in extractability of $\mathrm{Cr}$ and $\mathrm{Pb}$ in a polycontaminated soil after bioaugmentation with microbial producers of biosurfactants, organic acids and siderophores. Water Air Soil Pollut. 2006, 6, 261-279. [CrossRef]

147. Belimov, A.A.; Hontzeas, N.; Safronova, V.I.; Demchinskaya, S.V.; Piluzza, G.; Bullitta, S.; Glick, B.R. Cadmium-tolerant plant growth-promoting bacteria associated with the roots of indian mustard (Brassica Juncea L. Czern.). Soil. Biol. Biochem. 2005, 37, 241-250. [CrossRef]

148. Burd, G.I.; Dixon, D.G.; Glick, B.R. A plant growth-promoting bacterium that decreases nickel toxicity in seedlings. Appl. Environ. Microbiol. 1998, 64, 3663-3668. [CrossRef]

149. Burd, G.I.; Dixon, D.G.; Glick, B.R. Plant growth-promoting bacteria that decrease heavy metal toxicity in plants. Can. J. Microbiol. 2000, 46, 237-245. [CrossRef] 
150. Jiang, C.; Sheng, X.F.; Qian, M.; Wang, Q. Isolation and characterization of a heavy metal-resistant Burkholderia sp. from heavy metal-contaminated paddy field soil and its potential in promoting plant growth and heavy metal accumulation in metal-polluted soil. Chemosphere 2008, 72, 157-164. [CrossRef]

151. Kloepper, J.W.; Leong, J.; Teintze, M.; Schroth, M.N. Enhanced plant growth by siderophores produced by plant growth-promoting rhizobacteria. Nature 1980, 286, 885-886. [CrossRef]

152. Ghio, S.; Di Lorenzo, G.S.; Lia, V.; Talia, P.; Cataldi, A.; Grasso, D.; Campos, E. Isolation of Paenibacillus Sp. and Variovorax Sp. strains from decaying woods and characterization of their potential for cellulose deconstruction. Int. J. Biochem. Mol. Biol. 2012, 3 , 352-364. [PubMed]

153. Jadhav, H.P.; Sayyed, R.Z. Hydrolytic enzymes of rhizospheric microbes in crop protection. MOJ Cell Sci. Rep. 2016, 3, 135-136. [CrossRef] 